\title{
Results of Research to
}

Develop Cost Effective

Biomonitoring at Oil Shale

Lease Tracts: Phase I

Fall Sampling Report

\author{
J. R. Skalski \\ R. E. Fitzner \\ K. A. Gano
}

May 1982

Prepared for

the U.S. Geological Survey

under a Related Services Agreement

with the U.S. Department of Energy

under Contract DE-AC06-76RLO 1830

Pacific Northwest Laboratory

Operated for the U.S. Department of Energy

by Battelle Memorial Institute 


\section{DISCLAIMER}

This report was prepared as an account of work sponsored by an agency of the United States Government. Neither the United States Government nor any agency thereof, nor any of their employees, makes any warranty, express or implied, or assumes any legal liability or responsibility for the accuracy, completeness, or usefulness of any information, apparatus, product, or process disclosed, or represents that its use would not infringe privately owned rights. Reference herein to any specific commercial product, process, or service by trade name, trademark, manufacturer, or otherwise, does not necessarily constitute or imply its endorsement, recommendation, or favoring by the United States Government or any agency thereof. The views and opinions of authors expressed herein do not necessarily state or reflect those of the United States Government or any agency thereof.

\section{PACIFIC NORTHWEST LABORATORY operated by \\ BATTELLE \\ for the \\ UNITED STATES DEPARTMENT OF ENERGY under Contract DE-AC06-76RLO 1830}

\begin{tabular}{|c|c|}
\hline \multicolumn{2}{|c|}{ Printed in the United States of America } \\
\hline \multicolumn{2}{|c|}{$\begin{array}{c}\text { Available from } \\
\text { National Technical }\end{array}$} \\
\hline \multirow{4}{*}{\multicolumn{2}{|c|}{$\begin{array}{c}\text { National Technical Information Service } \\
\text { United States Department of Commerce } \\
5285 \text { Port Royal Road } \\
\text { Springfield, Virginia } 22151\end{array}$}} \\
\hline & \\
\hline & \\
\hline & \\
\hline \multirow{2}{*}{\multicolumn{2}{|c|}{$\begin{array}{l}\text { NTIS Price Codes } \\
\text { Microfiche A01 }\end{array}$}} \\
\hline & \\
\hline \multicolumn{2}{|c|}{ Printed Copy } \\
\hline & Price \\
\hline Pages & Codes \\
\hline $001-025$ & $\mathrm{~A} 02$ \\
\hline $026-050$ & A03 \\
\hline $051-075$ & A04 \\
\hline $076-100$ & A05 \\
\hline $101-125$ & A06 \\
\hline $126-150$ & $\mathrm{~A} 07$ \\
\hline $151-175$ & $A 08$ \\
\hline $176-200$ & A09 \\
\hline $201-225$ & A010 \\
\hline $226-250$ & A011 \\
\hline $251-275$ & A 012 \\
\hline $276-300$ & A013 \\
\hline
\end{tabular}


RESULTS OF RESEARCH TO DEVELOP COST EFFECTIVE BIOMONITORING AT OIL SHALE LEASE TRACTS: PHASE I

FALL SAMPLING REPORT
J. R. Skalski
R. E. Fitzner
K. A. Gano

May 1982

Prepared for the U.S. Geological Survey under a Related Services Agreement with the U.S. Department of Energy Contract DE-AC06-76RLO 1830

Pacific Northwest Laboratory

Richland, Washington 99352 


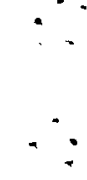




\section{CONTENTS}

INTRODUCTION

MONITORING OBJECTIVES

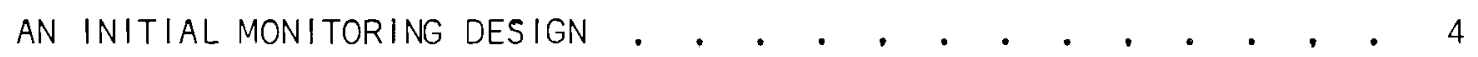

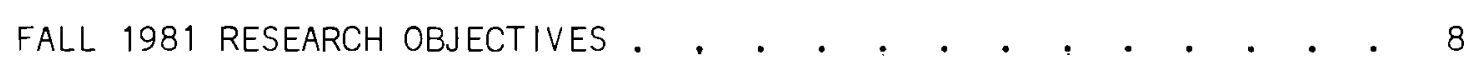

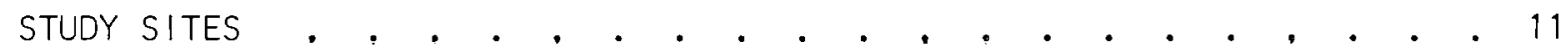

METHODS . . . . • . . . . . . . . . . . . . . . . . 17

SMALL MAMMAL CENSUSES • . . . • . • . . . . . . . . . 17

AVIFAUNA CENSUSES . . . . . . . . . . . . . . . . . . 18

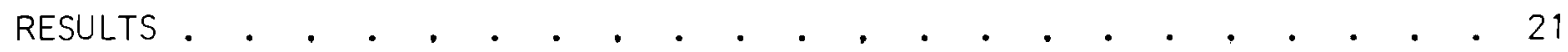

SMALL MAMMAL CENSUSES • • • . . . . . . . . . . . . . . . 21

Tests of Homogeneous Capture Probabilities . . . . . . 21

Abundance Estimates and Their Validity . . . . . . . . 24

Estimation of Variance Components . . . . . . . . 30

Cost Function for the Censuses . . . . . . . . . . 32

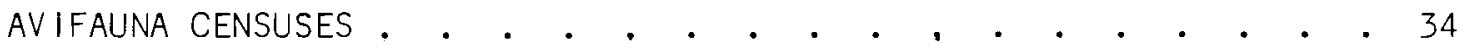

Tests of Homogeneous Detectability . . . . . . . . 34

Variability in Avifauna Abundance. . . . . . . . . 38

Cost Function for the Surveys . . . . . . . . , 40

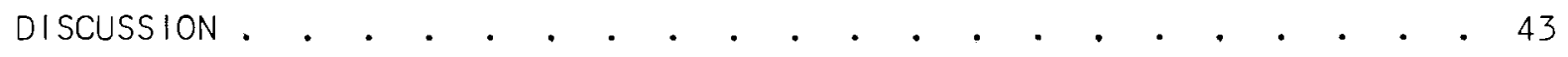

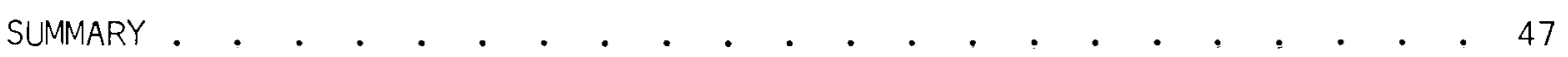

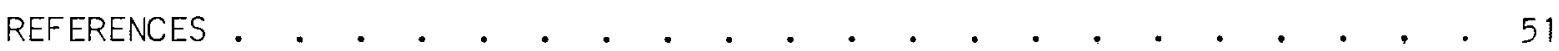

APPENDIX A - DATA MATRICES FROM SMALL MAMMAL CENSUSES • • • • • . . A.1

APPENDIX B - ILLUSTRATION OF THE SMALL MAMMAL DATA ANALYSIS • • • . B. 1

APPENDIX C - AVIFAUNA LINE-TRANSECT DATA . . . . . . . . . . . . C.1 


\section{FIGURES}

1 Map of Tract C-a Showing Study Site Locations for the Fall 1981 Small Mammal and Avifauna Censuses . . . . . . . . . .

TABLES

1 Location and Functional Description of the Six Sites Used for

Small Mammal and Avifauna Censuses near Tract $\mathrm{C}-\mathrm{a}$. . . . .

2 General Data Matrix Including the Sample Sizes, $\mathrm{n}_{\mathrm{i}}$, Numbers Marked, $x_{i m}$, and Numbers Unmarked, $x_{i u}$, During Marking $\left(i=1^{\prime}, 2,\right)^{\prime}$ and Removal $(i=1, \ldots, 3)$ Phases and Associated Summary Statistics for the Small Mammal Censuses . . . . .

3 Numbers of Distinct Individuals Captured of Different Species at the Six Small Mammal Plots 19-23 Oct 81 . . . . . . . . 22

4 Results of Tests of Homogeneous Capture Probabilities Using Mark-Recapture and Removal Sampling Data for P. maniculatus and E. minimus

5 Results of Tests of Goodness-of-Fit to the Geometric Removal Model and Tests of Equal Catchability for Marked and Unmarked P. maniculatus and E. minimus . . . . . . . . . . . . 26

6 Estimates of $P$. maniculatus Abundance on the Six 1-ha Plots in Sagebrush-Greasewood Communities in the Vicinity of Tract C-a . .

7 Estimates of $E$. minimus Abundance on the Six 1-ha Plots in Sagebrush-Greasewood Communities in the Vicinity of Tract C-a . .

8 Frequency of Occurence of the 18 Bird Species Sighted During the Course of 16 Line-Transect Surveys . . . . . . . . . 35

9 Analysis of Variance Table for Log-Transformed Perpendicular Sighting Distances Based on Observations from All Avifauna Species

10 Analysis of Variance Table for Log-Transformed Perpendicular Sighting Distances Based on Observations of $J$. hyemalis . . .

11 Total Bird Counts and Numbers of $J$. hyemalis Sighted During the 16 Line-Transect Surveys . . . . . . . . . . . . . 39

12 Analysis of Variance Table for the Latin Square Design Used in the Analysis of Total Bird Counts . . . . . . . . . .

13 Analysis of Variance Table for the Latin Square Design Used in the Analysis of Sighting Counts of $J$. hyemalis. 


\section{RESULTS OF RESEARCH TO DEVELOP COST EFFECTIVE BIOMONITORING}

AT OIL SHALE LEASE TRACTS:

PHASE I FALL SAMPLING REPORT

\section{INTRODUCTION}

The purpose of Paclfic Northwest Laboratory's (PNL's) ecological research at Piceance Basin. Colorado is to evaluate the feasibility of monitoring small mammal and avifauna populations by determining the levels of fleld effort required to detect reasonable changes in abundance which may result from oll shale development. In addition, where total sampling costs are not prohibitive, to provide statistically sound monitoring schemes based on costs and field data.

The objective of the Fall 1981 research was to initiate a faunal sampling program. The fall census period is conceptualized as the beginning of a two-phased research program to design monitoring schemes to test for impacts on small mammal and avifauna populations that might result from oil shale development at federal lease tracts. The purpose of the first phase of the program, of which this report on the fall sampling is part. is to conduct faunal censuses to estimate variance components needed to properly design monitoring studies and to test the validity of both indices and absolute abundance estimators (Seber 1973). The second phase of the program plan is the incorporation of the field data collected at the Piceance Basin to design monitoring schemes which embody information on:

1. site speclific characteristics of lease tracts,

2. observed variances in animal abundance,

3. Ilmited time and effort avallable for conducting monitoring studies,

4. and the quantitative objectives of a monitoring program. 
Hence the Fall 1981 research results are presented in the context of the objectives for conducting small mammal or avifauna monitoring and the potential monitoring designs available for quantitative impact assessment.

\section{MONITORING OBJECTIVES}

Censusing small mammal and avifauna populations is currently standard practice in monitoring programs at oll shale lease tracts administered by the U.S. Geological Survey. One apparent reason for monitoring faunal abundance is to establish baseline levels for eventual mitigation of any identified losses which result from physical disturbance at the lease tracts. In the case of open pit mining. such losses are both predictable and unavoldable.

The purpose of PNL's research on faunal monitoring is to assess the potential of small mammal and avifauna populations as biomonitors of various components of the terrestrial ecosystem. In this regard, monitoring schemes which are capable of detecting off-site impacts of oil shale development at federal lease tracts are of concern. Significant changes in small mammal or avifauna populations at off-tract locations which can be quantitatively assoclated with oll shale development, would implicate possible water or airborne effluents. We consider small mammals and, to an extent, breeding bird populations as promising biomonitors because:

1. the species can provide localized fate and effects assessments due to relatively small home range sizes,

2. large data bases exist on the ecology and physlology of the species (i.e., deer mouse (Peromyscus maniculatus),

3. the species represent an important prey base, 
4. permits can be readily obtained to collect small mammal speclmens for chemical analysis (fate),

5. costs of fleld studies are much less than for large vertebrates (i.e., raptors, mule deer (odocoileus hemionus).

Because animal abundance is an expression of both natural and man-induced ablotic and biotic factors, assessments at the population level seem appropriate. For this reason. we have emphasized developing monitoring schemes to detect changes in abundance as an ald in the identification of ecologically important impacts. Changes in small mammal populations would signal the need for intensifled environmental monitoring to identify causative agents based on the knowledge that biologically or physlologically significant effects have occurred. In contrast, the detection of increased levels of heavy metals. fluorldes or organic compounds may in themselves be insufficient evidence to warrant intensifled and costly environmental monitoring. Moreover, evidence from elevated tissue contaminant levels without assoclated data on ecological effects may be of IImited value in assessing the need for posslble changes in emmission control technology.

At least four major steps can be Identified In the ecological assessment of an energy technology. First, a quall tative evaluation or description of what is known about the environment and the technology is used to forecast potential environmental effects. The second step, both prior to and after a technology is initiated, is to monitor for ecological changes based on the forecasts and concerns identified in step one. At the third step, quantitative analysis of the monitoring data is conducted. If the assessment steps are properly integrated, the field study designs are specifically structured to detect and evaluate the impacts tested for in step three. The statistical and blological inferences derived from step three (for mitigation, deciding on additional monitoring, and feedback to step one) comprises the fourth step in an assessment. 
Because of the current state-of-the-art in ecological assessment, only descriptive data on population dynamics are typically collected using traditional fish and wildife census techniques. Such data are usually not relevant for quantitative evaluation of impacts (step three above). The monitoring schemes developed by the PNL research will be designed to detect impacts of a predetermined size $(\Delta)$ with a known certainty $(1-\beta)$. Based on these criterla, the reliability of using small mammals and avifauna as biomonitors is being evaluated and their usefulness in quantitative impact assessments determined.

\section{AN INUTLAL MONITORING DESIGN}

The interrelationship between the research goals of Phases 1 and 11 required that the Fall 1981 field study be conducted in conjunction with a design useful for monitoring programs. The principle requirement of an assessment design is that it must differentiate among changes in faunal abundance due to natural fluctuations and changes that result from impacts. Thus monitoring designs must be carefully structured and devised specifically for testing impact hypotheses in order to establish cause and effect relationships. Monitoring point-sources restricts the direct application of the traditional textbook experimental designs, when the objective is to quantify impacts. These restrictions include:

1. no randomization of treatments or controls to the landscape,

2. usually a single treatment area (the area influenced by the source) and only one to a few control areas are avallable.

3. replication of treatments are not possible or prohibitively expensive,

4. synchrony of regional populations resulting in autocorrelated and dependent observations. 
Some currently advocated monitoring methods (Green 1979) do not account for these design limitations.

While no proposed assessment design eliminates all the statistical Iimitations assoclated with point-source monitoring, control-treatment pairing (CTP) designs have several advantages over more traditional approaches (Eberhardt 1976, 1978; McKenzle et al. 1977; Skalski and McKenzie 1982). Because of the advantages of CTP design. the Fall 1981 research program was conducted with its use in mind. The purpose of this section is to brlefly discuss the basis of CTP designs and their advantages. The review of CTP designs is taken, in part, from a manuscript submitted for publication (Skalski and McKenzie, 1982).

The basic advantage of CTP designs is the use of spatial controls to account for temporal effects on dynamic systems (i.e., faunal communities). In a CTP design. potentially impacted (treatment) stations are paired with non-impacted (control) stations. The treatment stations are located within potential impact zones resulting from elther alrborne or waterborne effluents while the control sites are positioned outside the zones. As in classical experimental designs, the control areas are used to measure the effects of ambient conditions while the potential impact zones measure the same environmental conditions plus the effects of the hypothesized additional stimulus, (the impact).

In CTP designs, the control-treatment pairs are established during pre-operational monitoring and these station pairs are sampled into the operational period. Pre-operational sampling serves two functions. First, pre-operational sampling can be used to evaluate the success of the pairing scheme prior to the operational monitoring. More importantly, pre-operational sampling establishes the relationship between faunal abundance at control and treatment stations, (e.g. proportional abundance) which will be compared later with that observed during the operational perlod. With this ecological assessment scheme, an impact is defined as a statistically significant change in the proportional abundance of fauna at 
control and treatment stations between pre-operational and operational periods (Chapman 1951; Eberhardt 1976).

A pivotal assumption in the successful use of CTP designs is that faunal abundance at control and treatment stations "track" each other, i.e., maintain a constant proportionality. This tracking assures that populations at the control and treatment stations respond similarly to changes in environmental conditions. Unless this assumption is valid, there is no statistical way to determine if changes in abundance at the treatment stations during the operational period are the result of temporal variabllity or an impact. The detection of differences in faunal abundance between control and treatment stations or between the pre-operational and operational populations is insufficient evidence alone for assigning causation of population changes to a point source (l.e., oll shale development). Both spatial and temporal controls are necessary to establish cause and effect relationships for observed changes in faunal abundance.

With proper station pairing, the use of proportional abundance also can account for annual and seasonal changes in abundance. Removal of annual varlation allows repeated observations of a treatment combination between consecutive years to be designated as replicates. Thus, each year of the pre-operational or operational phase of the monitoring program is considered as one replicate in the analysis of CTP designs. It is this variation in proportional abundance between years which is used in testing the existence of ecological impacts. This removal of annual and seasonal changes in abundance also reduces the serlal correlation among successive observations of faunal abundance. Serial correlation has been shown to seriously hamper analysis of variance procedures (Scheffé 1959). However, unpaired monitoring designs cannot generate true replicate observations because of the inherent spatial and temporal heterogeneity of terrestrial systems. Replicate observations are generally assumed to be samples from a single population with constant mean and variance. 
When good control-treatment pairing is achieved, the variance of the difference in densitles between the control and treatment stations should be reduced. The varlance of the difference between two random variables, $x_{1}$ and $x_{2}$, can be expressed as

$$
\operatorname{Var}\left(x_{1}-x_{2}\right)=\operatorname{Var}\left(x_{1}\right)+\operatorname{Var}\left(x_{2}\right)-2 \operatorname{Cov}\left(x_{1}, x_{2}\right)
$$

With favorable pairing, the covariance in abundance between control and treatment stations should be positive, thus decreasing the observed variance and resulting in increased power for testing impact hypotheses. The decreased varlance can also be used to reduce the levels of monitoring effort needed to detect impacts of specified size. Mckenzle et al. (1977) compared the analyses of nuclear power plant monitoring data on zooplankton using both CTP designs and comparable unpaired experimental designs. He found up to a seven-fold reduction in the experimental error (MSE) assoclated with the use of CTP designs.

In summary, CTP designs have four distinct advantages over traditional unpalred designs frequently used in monitoring studies. These advantages are the following:

1. ability to relate changes in faunal abundance to oll shale development,

2. allows repeated observations of a control-treatment combination between years to be designated as replicates,

3. reduces or eliminates serial correlations among repeated observations on faunal abundance,

4. reduces the experimental error assoclated with the monitoring study. 
Because of these advantages and indications from other data collected at Piceance Basin of synchrony of populations, sites selected for small mammal and avifauna censuses were based on criterla used In CTP designs.

\section{EALL 1981 RESEARCH OBJECTIVES}

The purpose of the Fall 1981 research was to begin the collection of fleld data necessary to provide guidance in designing monitoring schemes at the federal oll shale lease tracts. The objectives of the fall censuses were to evaluate alternative census techniques, test assumptions vital to the use of indices and abundance estimators, determine cost-functions assoclated with monitoring effects, and estimate varlance components needed to devise optimal monitoring designs. Specific objectives of the fall research were as follows:

1. to estimate abundance of small mammals on repllcate plots and the assoclated varlance estimates using:

a. Lincoln Index (Seber 1973, pp. 59-60);

b. Removal sampling methods (Zippin 1956. 1958);

c. Mark-removal method (Skalski and Robson 1982, in press),

2. to test the validlty of the mark-recapture, removal and markremoval abundance estimates by means of statistical tests of goodness-of-fit, and tests of homogenelty presented in Skalski and Robson (1982, in press),

3. to test an assumption cruclal in using catch indices for small mammal populations, that of homogenelty of capture probabilities among animals of the different repllcate populations, by means of tests presented in Skalski and Robson, 1979, and Skalski. et al. 1982 (submitted), 
4. to estimate avifauna abundance and the associated sampling variance using line-transect methods and Fourier serles analyses (Burnham et al. 1980),

5. to determine if avifauna detectibility changes daily, diurnally or with habitat differences using analysis of varlance and Fourler series procedures, (Results will indicate whether count indices or absolute abundance estimators are needed in monitoring avifauna populations at Piceance Basin.)

6. to estimate the plot-to-plot variance component assoclated with the faunal censuses,

7. to formulate cost functions associated with faunal censusing in multiple-plot studies. 
-

$\therefore$

. 


\section{STUDY SITES}

Sites were selected for the Fall 1981 research with two objectives, 1) estimation of the plot-to-plot variance in animal abundance and 2) Illustration and testing of the application of CTP designs at federal lease tracts. Six sites in the vicinity of Federal Lease Tract C-a were selected for these purposes. The six sites were paired between three gulches within constraints of the topography such that two sites were north of Tract C-a, two sites were south of $\mathrm{C}-\mathrm{a}$ and two sites were directly downwind of the C-a tract. Within each pair of sites, one site was located in the near vicinity of Tract C-a while the other site was located $5 \mathrm{~km}$ or more further downwind of the tract (Figure 1).

In the context of CTP designs, the pair of sites in Corral Gulch-Yellow Creek Gulch ( $\mathrm{C} 1$ and $\mathrm{C} 2$ ) represent areas along a potentlal treatment or impact gradient (Table 1). The sites In Ryan Gulch (R1 and R2) were selected because they represent areas along a southern control or non-impacted gradient. Similarly, the pair of sites in Duck Creek-Yellow Creek Gulch (D1 and D2) represent areas along a northern control gradient. Each pair of sltes would be used in a CTP design to estimate proportional abundance during pre-operational and operational phases of the oil shale development of Tract $\mathrm{C}-\mathrm{a}$. The proportional abundance computed by sites $\mathrm{C} 1$ and $\mathrm{C} 2$ would be expected to change if site $\mathrm{C} 1$ was impacted by plant operations and this change would be detected relative to the proportional abundance computed by R1 and R2 to the south and D1 and D2 to the north of Tract C-a.

A properly implemented monitoring design consists of replicate study plots in both control/non-impacted and treatment/impacted areas and this was the basis for the Fall 1981 site selection. However, criterla used in selection are dependent upon the objectives of the field study. A distinction needs to be made between the objectives of estimation and hypothesis testing. If the objective was solely to estimate mean faunal 


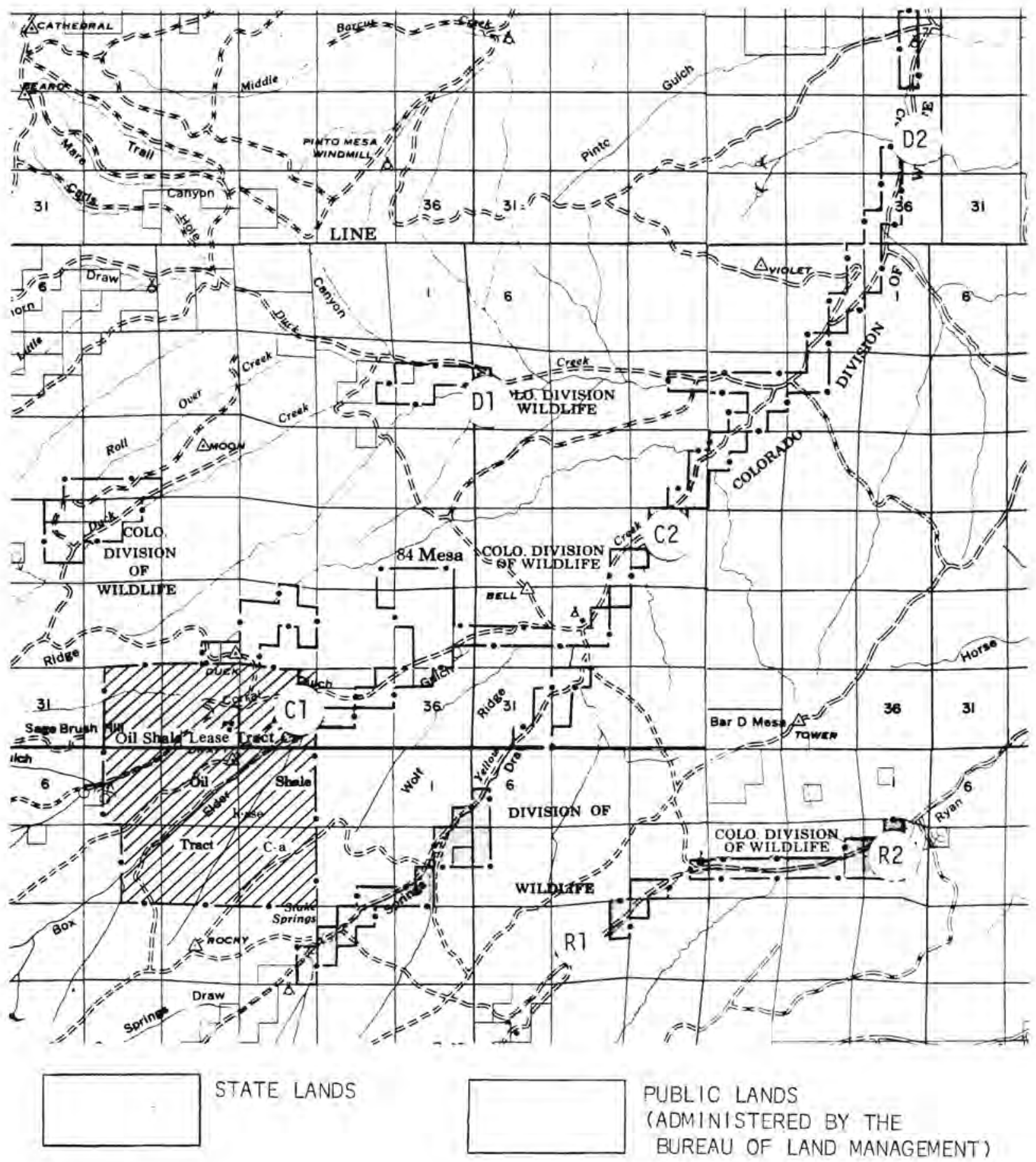

FIGURE 1. Map of Tract C-a Showing Study Site Locations for the Fall 1981 Small Mammal and Avifauna Censuses 


\section{TABLE 1. Location and Functional Description of the \\ Six Sites Used for Small Mammal and Avifauna \\ Censuses near Tract $\mathrm{C}$-a}

$\begin{array}{ccc}\begin{array}{c}\text { Code } \\ \text { Designation }\end{array} & \frac{\text { Location }}{\text { C1 }} \\ \text { C2 } & \text { T.1S., R.99W., Section } 34 \\ \text { D1 } & \text { T.1S., R.99W., Section } 12 \\ \text { D2 } & \text { T.1S., R.98W., Section } 25 \\ \text { R1 } & \text { T.2S., R.98W., Section } 27 \\ \text { R2 } & \text { T.2S., R.98W., Section } 12\end{array}$

Functional Description in a CTP Design
Treatment site along a potential impact gradient
Control site along a potential impact gradient
Treatment site along a control gradient
Control site along a control gradient
Treatment site along a control gradient
Control site along a control gradient


abundance in Plceance Basin, a form of random sampling or stratlfied random sampling would have been acceptable. In Impact assessment, the objective is testing the hypothes is of no impact. Hence, a more restrlctive set of criterla were used in the selection of sites for the Fall 1981 research.

With the purpose of hypothes is testing, replicate plots were selected purposely for their similarity. These similar or "replicate" plots were, in addition, selected for their location relative to potential control and impact areas. A single habitat type in a single terrain was selected for the sites because the more similar these replicate plots, the smaller the plot-to-plot varlance in animal abundance should be, and the greater the Ilkel ihood impacts wlll be detected. The six replicate sites were located in sagebrush-greasewood (Artemisia tridentata - Sarcobatus vermiculatus) communities and all in gulch environments.

The sagebrush-greasewood community represents just one of several repetitive habitat types that could have been selected. The gulch environment was chosen as the location of the sites for several reasons, these include:

- location of the cold air dralnage and water seepage from the lease tracts and so resulting in areas of potential impact.

- habitats with high small mammal abundance,

- repetitive feature of the landscape,

- individually isolated by topography,

- habitats least likely to be physically disturbed by development,

- orientation of development with gulch locations,

- accessibility. 
While the six sites used during Fall 1981 illustrate some of the principles of CTP designs, they do not necessarlly constitute a complete assessment design. One of the objectives of Phase 11 research is to determine the level of field replication needed to detect with assurance. $(1-\beta)$, reasonable changes in population abundance $(\Delta)$ the result of oll shaie development. 


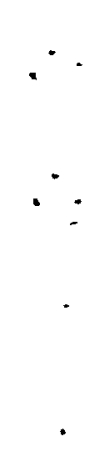




\section{METHODS}

\section{SMALL MAMMAL CENSUSES}

Six 1-ha plots for censusing small mammal abundance were established In the vicinity of Tract $\mathrm{C}-\mathrm{a}$ at sites $\mathrm{C} 1, \mathrm{C} 2, \mathrm{D1}, \mathrm{D2}, \mathrm{R} 1$, and R2 (Figure 1). All six plots were established in similar sagebrush-greasewood communities and located near the middle of the gulches. Traps were set $10 \mathrm{~m}$ apart in a $10 \times 10 \mathrm{grid}$ on each plot with trapping conducted simultaneously at all six areas. Trapping was conducted for five consecutive days (19-23 Oct 81) with two days of live trapping for marking the animals followed by three days of removal trapping. All trapping was conducted using Sherman live traps. Small mammals captured during the marking period were dye marked and released at respective points of capture. Species and sex were recorded for all animals captured.

Results of the mark-recapture study were summarized in a general data matrix (Skalski and Robson 1982) for each of the six plots and by species (deer mice (Peromyscus maniculatus), least chipmunk (Eutamius minimus)). Data from the matrices (Table 2) were used to estimate small mammal abundance by means of mark-recapture (Seber 1973, pp. 59-69), removal sampling methods (Zippin 1956, 1958) and the mark-removal method (Skalski and Robson 1982, in press). The validity of the absolute abundance procedures were tested by means of statistical tests of goodness-of-fit. and tests of homogenelty presented in Skalski and Robson (1979) and Skalski and Robson (1982, in press).

The homogeneity of capture probabllitles among animals of the six different replicate populations was tested using both mark-recapture (Skalski et al. 1982, submitted) and removal sampling data (Skalski and Robson 1979). Results of the tests of homogenelty were used to determine whether simple catch Indices rather than absolute abundance methods may be most approprlate for comparing small mammal abundance at Piceance Basin. 
TABLE 2. General Data Matrix Including the Sample Sizes, $n_{i}$, Numbers Marked, $x_{i m}$, and Numbers Unmarked, $x_{i}$, During Marking $\left(i=1^{\prime}, 2^{\prime}\right)^{\prime}$ and Removal $(i=1, \ldots, 3)$ Phases and Associated Summary Statistics for the Small Mammal Censuses

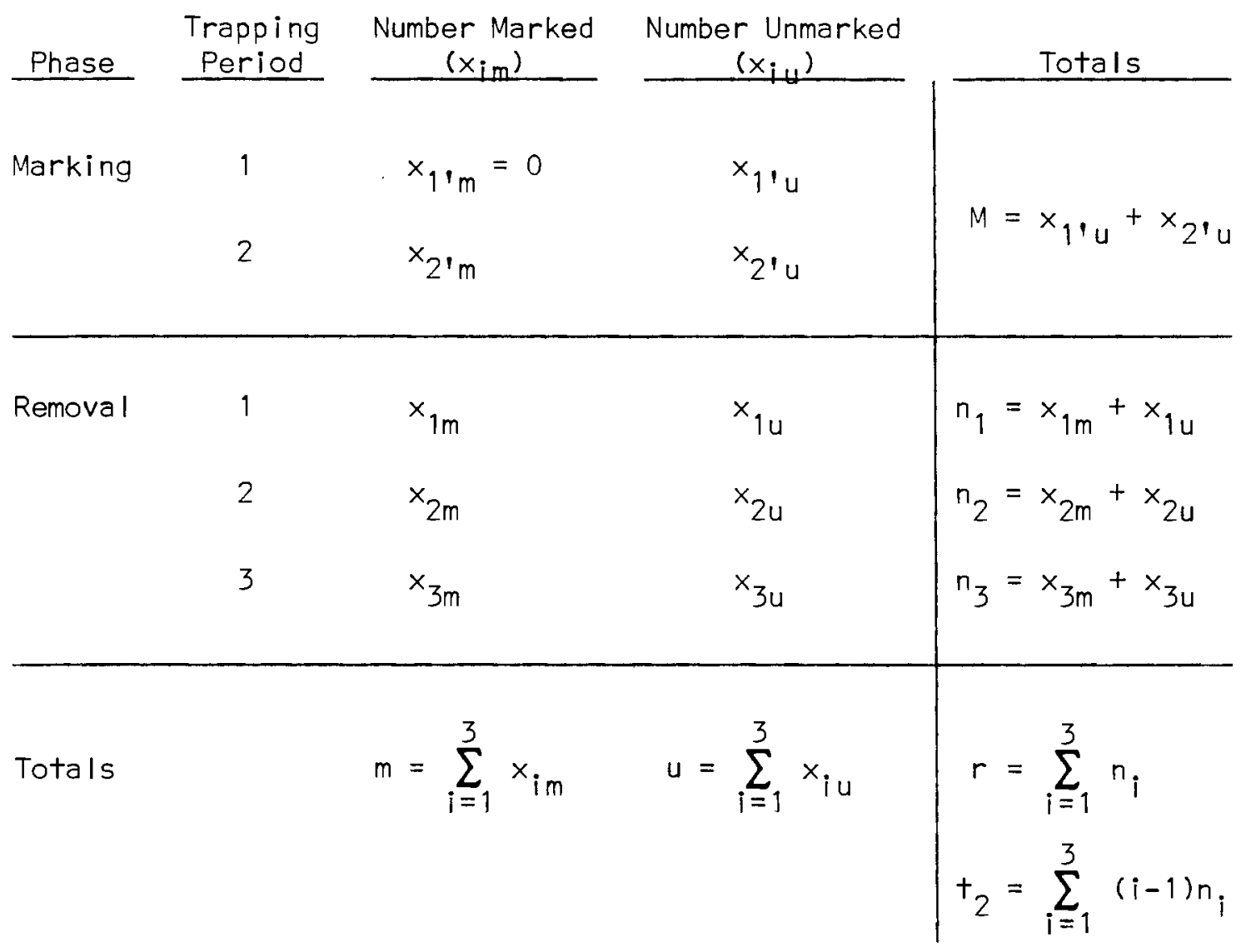

\section{AVIFAUNA CENSUSES}

Four $1.5-\mathrm{km}$ line transects for use in avifauna censusing were established in the vicinity of Tract C-a at sites D1, D2, R1 and R2 (Figure 1). A Latin-square design was used in scheduling of the avifauna surveys. Surveys were conducted on 16,17, 18 and 20 oct 81 with each transect surveyed during one of four sampling periods on each day. The dally sampling periods corresponded to the times 8:00-9:15 a.m., 9:45-11:15 a.m., $11: 45$ a.m. $-1: 15$ p.m. and 1:45-3:00 p.m. with each survey requiring 1-1.25 
hr to complete. A total of 16 avifauna censuses were conducted. Species, sighting distance and sighting angle were recorded for each bird observed during the study.

Analysis of variance (ANOVA) procedures for Latin-square designs were used in the analysis of the avifauna survey data. Total bird counts and counts of dark-eyed junco (Junco hyemalis) were analyzed to test for effects of time of day. daily differences and plot-to-plot differences in bird counts. The Latin-square design provided six degrees of freedom to estimate the varlance in bird counts.

Using the individual observations on sighting distance and angle, the sighting data were converted to perpendicular distances and log-transformed. Analysis of variance procedures tested whether the mean perpendicular sight distance was effected by the time of day the survey was conducted, dally differences and plot-to-plot differences. The ANOVA procedures served as tests of homogeneous detectibllity and were used to determine whether indices such as bird counts or absolute abundance procedures (Burnham et al. 1980) were necessary in monitoring fall avifauna abundance. 


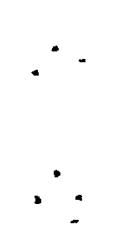




\section{RESULTS}

\section{SMALL MAMMAL CENSUSES}

During the 3000 trap-nights of effort used to conduct the Fall 1981 censuses, 383 small mammals were captured on the six study plots in sagebrush-greasewood communities (Table 3 ). Deer mice (Peromyscus maniculatus) constituted $70.0 \%$ of the catch and least chipmunks (Eutamius minimus) $28.5 \%$ of the small mammals trapped.

\section{Iests of Homegeneous Capture Probabilities}

When the purpose of conducting animal censuses is for the quantitative comparison of populations, absolute abundance procedures are no longer used to estimate animal numbers, but rather to estimate capture probabilities (Skalski et al. 1982, submitted). When the probabllities can be assumed equal, comparative techniques based on population indices (the number of distinct animals trapped) have been shown to be up to 20 times more efficient as comparable methods based on abundance estimates (Skalski et al. 1982, submitted). Tests of homogeneity based on capture data can be used to determine whether these capture probabilities are equal among populations being compared. If the capture rates are found to be unequal, estimates of the probabilities can be used to adjust the indices to still provide valid statistical comparisons of abundance. Catch data from Piceance Basin were used to test whether the simplier and more efficient indices of abundance could be used in assessment programs at the lease tracts.

Both the mark-recapture and removal sampling data (Appendlx A) were used to test for homogeneous capture probabilities among small mammals of the six replicate plots. The purpose of the tests was to determine whether capture probabilities were similar in populations censused simultaneously to eliminate potential temporal effects on catchability. Catch rates of 
TABLE 3. Numbers of Distinct Individuals Captured of Different Species at the Six Small Mamma I Plots 19-23 Oct 81

\begin{tabular}{|c|c|c|c|c|c|c|c|}
\hline Species & $\underline{C 1}$ & $\underline{\mathrm{C} 2}$ & $\underline{\mathrm{D} 1}$ & $\underline{\mathrm{D} 2}$ & $\underline{R} 1$ & $\underline{\mathrm{R} 2}$ & $\begin{array}{c}\text { Species } \\
\text { Total } \\
\end{array}$ \\
\hline Peromyscus maniculatus & 53 & 76 & 48 & 35 & 34 & 22 & 268 \\
\hline Eutcomias minimus & 11 & 4 & 29 & 18 & 18 & 29 & 109 \\
\hline Mustela erminea & 1 & 0 & 0 & 1 & 0 & 0 & 2 \\
\hline Mustela frenata & 1 & 0 & 0 & 0 & 0 & 0 & 1 \\
\hline Microtus montanus & 0 & 1 & 0 & 0 & 0 & 0 & 1 \\
\hline Reithrodontomys megalotis & 0 & 1 & 0 & 0 & 0 & 0 & 1 \\
\hline Perognathus spp. & 0 & 0 & 1 & 0 & 0 & 0 & 1 \\
\hline Plot Total & 66 & 82 & 78 & 54 & 52 & 51 & 383 \\
\hline
\end{tabular}

gray squirrels (Sciumus carolinensis) have been shown to be affected by habitat differences (Perry et al. 1977). Weather factors (Getz 1961, Mystkowska and Sidorowicz 1951, Gentry et al. 1966) and seasonal changes (Klonglan 1955, Perry et al. 1977) also have been shown to influence capture rates.

Using the vectors of catch data $(M-m, m, u)$ from each small mammal plot, a chi-square test of homogenelty was constructed using a $3 \times 6$ contingency table with ten degrees of freedom (d.f.) (Skalski et al. 1982, submitted) for the P. maniculatus and E. minimus data. The tests of homogeneity were used to determine whether the capture probabilities during the 2-day marking and the 3-day removal sampling periods were equal for the six populations compared. The null hypothesis of homogeneity was rejected 
TABLE 4. Results of Tests of Homogeneous Capture Probabilities Using Mark-Recapture and Removal Sampling Data for $P$, maniculatus and E. minimus

\begin{tabular}{|c|c|c|c|c|}
\hline \multirow[b]{2}{*}{ Species } & \multicolumn{2}{|c|}{ Mark-Recapture Sampling } & \multicolumn{2}{|c|}{ Removal Sampling } \\
\hline & $\begin{array}{c}\text { Test Statistic } \\
\left(x_{10}^{2}\right)\end{array}$ & $\alpha$-Level & $\begin{array}{c}\text { Test Statistic } \\
\left(x_{5}^{2}\right)\end{array}$ & $\alpha$-Level \\
\hline P. maniculatus & 20.26 & 0.027 & 2.29 & 0.808 \\
\hline E. minimus & 16.22 & 0.093 & 4.04 & 0.544 \\
\hline
\end{tabular}

for the $P$. maniculatus data $(\alpha<0.05)$ but was not rejected for the E. minimus data $(0.10<\alpha<0.05$ ) (Table 4).

Similarily, using the vectors of removal data $\left(n_{1}, n_{2}, n_{3}\right)$ from the six plots, tests of homogenelty were constructed using the Q-statistic (Skalski and Robson 1979) distributed as a chi-square with 5 d.f. The tests were used to determine whether capture probabilities during the 3-day removal period alone were equal for the six populations. Hypotheses of homogeneity were not rejected $(\alpha>0.05)$ for elther the $P$. maniculatus or E. minimus data (Table 4).

The homogeneity in capture probabilities during the 3-day removal period suggests differences in catchablility may only have existed during the marking perlod. The trap mortality which occurred (Appendix A) during marking may be a consequence of stresses also experienced by the $P$. maniculatus which were marked and released back into the populations. If such stresses existed, the effects of marking and handing the animals may have resulted in unequal and differential catchability in the replicate populations. Therefore, the observed heterogenelty may be an artifact of handling practices and not inherent differences in the catchabillty of small mammals between plots. Additional tests scheduled for spring and summer 1982 sampling periods wlll add Information about the existance of 
spatial effects on catchability of small mammals. At present the possibility exists that indices may be valld means of population comparison of small mammals at federal lease tracts.

\section{Abundance Estimates and Their Yalidity}

A rational choice on which census procedure to use in a study such as at Piceance Basin is difficult because the validity of a proposed abundance estimator can only be determined a posteriori, if determined at all. Therefore, a census procedure was chosen for the Fall 1981 field research which yields capture data conformable to a number of models. It was hoped that by the incorporation of a number of techniques, at least one might provide valid estimates of small mammal abundance. An additional constralnt in the selection of possible methods was to find a field procedure which was efficlent enough to provide precise abundance estimates with reasonable levels of effort.

in impact assessment studies, multiple plots will be necessary and the populations on those plots censused to validly test the hypotheses of no impact. Eberhardt (1978) states that as in the case of classical designs, it is the plot-to-plot variance which must be estimated and used to test impact hypotheses. The necessity for repllcate plots across the landscape precludes the practice of intense characterization of the population dynamics on just a few representative plots. Field methods must focus on census techniques which can estimate abundance with minimal effort and yet be robust to changing requirements imposed on the estimators the result of fluctuating environmental conditions.

The mark-removal method (Skalski and Robson 1982, In press) was chosen for the Fall 1981 small mammál censuses because of its flexibility and because abundance estimates can be obtained in relatively short perlods of time, say a 5-day trapping session. The multiple mark-recapture methods of 
Otis et al. (1978) also provide for flexible data analysis but the procedure was considered to be too labor Intensive for routine monitoring studies as are belng Investigated at Piceance Basin.

The choice of the proper abundance estimator using the data from the mark-removal field procedure (Appendix A) depends on the validity of two assumptions. These assumptions are:

1. Marked and unmarked animals have equal probabilities of capture during the 3-day removal sampling phase of the census.

2. The probability of capture is constant during the three days of removal sampling (i.e., goodness-of-fit to a geometric removal model).

Depending on the valldity of the above assumptions, small mammal abundance on a plot can be estimated using mark-recapture, removal sampling, or mark-removal estimators (Skalski and Robson 1982, in press). The statistical tests of these assumptions are presented in Skalski and Robson (1979, 1982, in press).

The homogeneity of capture probabilities during the removal period permitted the catch data (Appendix $A$ ) to be pooled from the six plots for testing goodness-of-fit to the removal model. Goodness-of-fit was then tested by two means. The total catch (marked and unmarked animals) and the captures from unmarked animals were tested by statistics for goodness-of-fit to a geometric model for removal sampling developed by Skalski and Robson (1979) and presented later In Skaiski and Robson (1982, in press) (Table 5). Exploiting the fact that the population abundance of marked animals is known at the onset of removal sampling, an alternative goodness-of-fit test (Skalski and Robson 1982, in press) for just the marked population was performed (Table 5). This later test has less power but is sensitive to a wider variety of violations of assumptions, including 
TABLE 5. Results of Tests of Goodness-of-Fit to the Geometric Removal Model and Tests of Equal Catchability for Marked and Unmarked P. maniculatus and E. minimus*

Tests of Assumptions

1. Goodness-of-fit to geometric removal model

Total catch

Unmarked animals only

2. Goodness-of-fIt

Marked animals only

3. Equal catchablilty of marked and unmarked animals in removal phase

Total catch
P. manioulatus

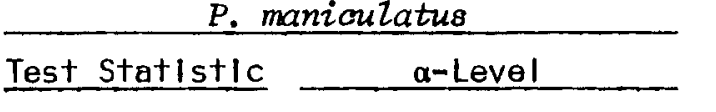

E. minimus

Test Statistic

$\alpha-$ Level

$$
\begin{array}{ll}
Z=0.274 & P(Z>0.274)=0.392 \\
Z=0.425 & P(Z>0.425)=0.335
\end{array}
$$$$
z=0.147
$$$$
Z=-0.161
$$$$
P(Z>-0.161)=0.564
$$

$z=-1,523$

$P(Z<-1.523)=0.064$

$Z=-1.315$

$P(Z<-1.315)=0.094$$$
P(z<-1.315)=0.094
$$

* Tests based on the catch data pooled from the six replicate plots. 
lack of closure. Results of these goodness-of-fit tests suggest that while the unmarked populations may well fit the removal model, marked P. maniculatus and E. minimus may not $(0.10>\alpha>0.05)$.

A test of the assumption of equal catchabllity of marked and unmarked animals during the removal sampling is exactly equivalent, in type, to the tests of homogeneity performed earlier to determine whether capture probabilities were equivalent between populations during the removal sampling. The tests of homogeneity (Table 5) indicated significant heterogeneity in capture probabllities between marked and unmarked animals In populations of $P$. maniculatus and E. minimus. Consequently, mark-recapture type estimators were not considered to be valid means of estimating abundance using the small mammal data from the Fall 1981 censuses.

Interpretation of the tests of assumptions suggest that while the removal samples for the unmarked segments of the six populations censused are homogeneous and conform to a geometric removal model. capture probabilities for marked animals differ from the unmarked individuals and do not conform to that expected under a geometric removal model. These results are consistent with what might be expected if marking had an effect on the small mammals which were handled, changing their behavior and trap response. With this configuration of census results, small mammal abundance was estimated by adding to the marked populations, estimates of the unmarked animals remaining in each population computed by means of the removal estimator (Zippin 1956, 1958).

The abundance estimates for small mammals on each plot were computed according to the formula:

$$
\hat{N}_{i}=M_{i}^{\prime}+\frac{u_{i}}{\left(1-\hat{q}^{3}\right)} \quad \text { for } i=1, \ldots, 6
$$


where $\hat{N}_{i}=$ estimate of abundance on the ith plot, $1=1, \ldots, 6$

$$
\begin{aligned}
& M_{i}{ }^{\prime}=\text { number of animals marked }(M) \text { plus handing mortalities on } \\
& u_{i}=\text { number of unmarked animals captured durlng the three days } \\
& \text { of removal sampling on the } i \text { th } p l o t, 1=1, \ldots, 6 \\
& \hat{q}=(1-\hat{p})=\text { pooled estimate of the daily probability of } \\
& \text { escaping capture for unmarked animals on the } \\
& \text { six plots. }
\end{aligned}
$$

The estimate $\hat{p}$ was computed according to the formula

$$
\hat{p}=\frac{5 u \cdot-3 t_{2}-\left(u .^{2}+6 u \cdot t_{2}-3 t_{2}{ }^{2}\right)^{1 / 2}}{\left(4 u \cdot-2 t_{2 .}\right)}
$$

and where $u_{.}=\sum_{i=1}^{6} u_{i}=\sum_{i=1}^{6} \sum_{j=1}^{3} x_{i j u}$

$$
t_{2 .}=\sum_{i=1}^{6} \sum_{j=2}^{3}(j-1) x_{i j u}
$$

are summary statistics for the removal sampling data for unmarked animals summed over the six replicate plots. Dally capture probabilites for P. manicuzatus and E. minimus were estimated at 0.390 and 0.608 , respectively.

Mean abundance for $P$. maniculatus per plot ( 1 ha) was estimated at 50.5 animals, with a range in abundance of $25.2-84.5$ (Table 6). Mean abundance of $E$. minimus was less in these sagebrush-greasewood communities with an average of 19.1 animals, and a range in numbers of $4.2-31.9$ (Table 7). The coefficients of variation for abundance between replicate 
TABLE 6. Estimates of $P$. maniculatus Abundance on the Six 1-ha Plots in Sagebrush-Greasewood Communities in the Vicinity of Tract C-a

\begin{tabular}{|c|c|c|c|c|c|c|}
\hline & \multicolumn{6}{|c|}{ Small Mamma I Plots } \\
\hline & $\mathrm{C} 1$ & $\mathrm{C} 2$ & D1 & $\mathrm{D} 2$ & R1 & $\mathrm{R} 2$ \\
\hline $\begin{array}{l}\text { Numbers captured during } \\
\text { marking period }\left(M^{\prime}\right)\end{array}$ & 30 & 47 & 23 & 21 & 16 & 11 \\
\hline Estimated unmarked & 29.8 & 37.5 & 32.3 & 18.1 & 23.3 & 14.2 \\
\hline Estimated abundance $(\hat{N})$ & 59.8 & 84,5 & 55.3 & 39.1 & 39.3 & 25 \\
\hline
\end{tabular}

TABLE 7. Estimates of E. minimus Abundance on the Six 1-ha Plots in Sagebrush-Greasewood Communities in the Vicinity of Tract C-a

\begin{tabular}{|c|c|c|c|c|c|c|}
\hline & \multicolumn{3}{|c|}{ Sma ll Mamma } & \multicolumn{2}{|c|}{ Plots } & \multirow[b]{2}{*}{$\mathrm{R} 2$} \\
\hline & $\overline{\mathrm{C} 1}$ & $\mathrm{C} 2$ & D1 & D2 & R1 & \\
\hline $\begin{array}{c}\text { Numbers captured during } \\
\text { marking period }\left(M^{\prime}\right)\end{array}$ & 6 & 1 & 17 & 12 & 5 & 17 \\
\hline Estimated unmarked & 5.3 & 3.2 & 12.8 & 6.4 & 13.8 & 14.9 \\
\hline Estimated abundance $(\hat{N})$ & 11.3 & 4.2 & 29.8 & 18.4 & 18.8 & 31.9 \\
\hline
\end{tabular}


plots for $P$. maniculatus and $E$. minimus were $41.1 \%$ and $55.5 \%$.

respectively. Illustrations of the statistical analyses of the small mammal data are presented in Appendix $B$.

\section{Estimation of Varlance Components}

A primary purpose in Phase il research is to determine the levels of field effort required to detect impacts of reasonable size ( $\Delta$ ) on populations of small mammals and avifauna. Monitoring efforts to detect such changes will be determined in terms of the numbers of replicate study plots needed for an assessment and the levels of effort required to precisely census faunal abundance on each repilcate plot. To provide for optimal allocation of efforts between and within plots, estimates of the sampling error and plot-to-plot variance in faunal abundance in the vicinity of a lease tract will be necessary. Using the fall census data. initial estimates can be computed. Additional sampling planned for spring and summer 1982 will help determine whether such estimates are seasonally dependent.

Based on findings that the capture probabillities were homogeneous across plots during the three days of removal sampling and that the data fit sufflciently well to the removal model, varlance components were estimated based on the removal data. The removal data from the marked animals were included in these calculations because for the purpose of variance estimation, the high overall removal rates should sufficiently dampen any heterogeneity that may exist between individuals in a population and permlt reliable estimation (Seber and whale 1970).

\section{Let $r_{i}$ define the number of distinct animals captured on plot $i$} during the three day removal sampling period and $\mathrm{N}_{i}$ the animal abundance on plot i. Then we can write the identity

$$
r_{i}=E\left(r_{i}\right)+\left[E\left(r_{i} \mid N_{i}\right)-E\left(r_{i}\right)\right]+\left[r_{i}-E\left(r_{i} \mid N_{i}\right)\right]
$$


and taking expected values

$$
r_{i}=\mu p^{\prime}+\left(N_{i} p^{\prime}-\mu p^{\prime}\right)+\left(r_{i}-N_{i} p^{\prime}\right)
$$

Expression (1) describes the catch at plot i by a I inear model composed of a mean catch of $\mu p^{\prime}$ plus deviations attributable to between-plot differences in abundance $\left(N_{i} p^{\prime}-\mu p^{\prime}\right)$ and sampling error $\left(r_{i}-N_{i} P^{\prime}\right)$. Taking the varlance of (1), the variance of $r_{1}$ is found to be

$$
\operatorname{Var}\left(r_{i}\right)=p^{\prime 2} \sigma_{N}^{2}+\mu p^{\prime} q^{\prime}
$$

where $\sigma_{N}^{2}=$ varlance in animal abundance $N_{i}$ between plots, and $\quad p^{\prime}=$ three-day capture probability $=\left(1-q^{3}\right)$.

Expression (2) forms the basls for the estimation of variance components.

Using the removal data from the six plots and pooling the observations $\left(n_{1}=120, n_{2}=46, n_{3}=21\right)$ estimates of the mean abundance $(\mu)$ and the capture probabllity $\left(1-q^{3}\right)$ were computed (Zippin 1956, 1958) for $P$. maniculatus. The pooled data estimated $\hat{\mu}=33.44$ and $\hat{p}^{\prime}=0.9321$. By equating (2) to the observed sampling varlance of $r_{i}$ for the six plots and using the pooled estimates $\hat{\mu}$ and $\hat{p}^{\prime}$, the plot-to-plot varlance was found to be 214.61. The expression $\mu p q$ then estimates the sampling error at 2.12 during the three days of removal sampling for the censuses of $P$. maniculatus.

In a similar manner. varlance components were estimated based on the pooled removal data $\left(n_{1}=80, n_{2}=17, n_{3}=5\right)$ from the censuses of E. minimus. The pooled data estimated $\hat{\mu}=17.22$ and $\hat{p}^{\prime}=0.987$. Consequently, the plot-to-plot variance in E. minimus was estimated at 85.93 and the sampling error associated with the removal sampling during the Fall 1981 censuses was 0.21 . 
These results indicate that animal abundance on the Individual plots were estimated with high precision during Fall 1981. Further, the coefficlents of varlation for the abundance of $P$. maniculatus and E. minimus ( $41.1 \%$ and $55.5 \%$. respectively) are almost totally the result of actual differences in abundance between plots, say the plot-to-plot variance. There was a 100-fold difference in the size of the varlance components for the between and within plot errors.

The estimates of the variance components strongely suggest that "extensive" rather than "intensive" sampling schemes should be used in the monitoring of the small mammal populations. In other words, numerous replicate plots placed across the landscape will be necessary to account for the relatively large size of the plot-to-plot variance and these populations need to be sampled only superficlaily. Such a scheme puts the monitoring efforts where the variances are the greatest and where the returns in improved precision are the most likely. Suggestions on exact al locations for effort between and within plots will be part of future work on this continuing project. Additional sampling and data reviews will be used to establish whether the high capture probabilities ( $p^{\prime}>0.90$ ) are typical or are seasonally dependent. Changes in capture probabllities with changing seasons may require alternative allocation schemes.

\section{Cost Function for the Censuses}

Besides estimates of the variance in small mammal abundance, cost functions for multi-plot surveys are necessary to optimally allocate monitoring efforts. A cost function expresses in monetary terms the costs of data collection based on the numbers of replicate plots and the trapping effort per plot. During Fall 1981 the expenditures of time spent on locating the study sites, site preparation and trapping efforts were recorded to construct realistic formulations describing field costs. 
As a working premise, the basic unit of effort was considered to be a 2-person hour. In other words. one hour of labor spent by a 2-person field crew. Hence, subsequent calculations are based on the efficiency of 2-person fleld teams, and probably cannot be extrapolated or be considered equivalent to one person working for two hours. Locating the six small mammal plots required 22 units of effort, site preparation 31 units and trapping small mammals 64.5 units of effort.

A potentlal cost function describing the small mammal field work can be expressed in terms of four components. These are:

1. Fixed costs assoclated with the initiation any study, independent of of size. These costs include travel to the area, orlentation and equipment preparation.

2. Costs assoclated with the location of the study sites and which should be directly proportional to the number of plots chosen.

3. Costs assoclated with site preparation including equipment purchases and field layouts. These costs may be consldered as a first approximation to be directly related to the size of the study plots.

4. Costs directly assoclated with conducting the faunal censuses and again as a first approximation may be considered to be directly related to the number of study plots.

The amount of fixed costs will depend on who is conducting the study. Such costs may differ if environmental consultants, universities or the oll companies themselves conduct the monitoring projects. Locating study sites required approximately 0.5 days of effort per site based on experience from Fall 1981. The costs of site preparation include equipment and fleld labor, and on a per trap basis, labor amounts to 0.0065 days/trap/plot. Using the mark-removal method as a possible census method or something equivalent, six days of trapping effort are necessary to conduct the 
censuses. However, based on the Fall 1981 experlences, a 2-person team will be necessary for every four plots established.

Based on labor expenditures from the Fall 1981 fleld research, the following cost function was established:

$$
\operatorname{cosTS}=A+0,5 B X+(C+0.0065 B) X Y+6 B\left[\frac{X}{4}\right]
$$

where $A=f$ ixed costs,

$B=$ cost of one day support, labor, and transportation for a 2-person fleld crew,

$C=$ per trap cost plus any additional materlals needed to mark lts location,

$X=$ number of plots,

$Y=$ number of traps per plot,

and where [] denotes the smallest integer that is greater than or equal to the expression.

\section{AVIEAUNA CENSUSES}

A total of 258 birds among 18 avifauna specles were sighted during the course of the 16 line-transect surveys (Table 8). An average of 16.1 birds were sighted per survey using I ine-transects of length $1.5 \mathrm{~km}$. The most commonly sighted species was the dark-eyed junco (Junco hyemalis) which accounted for $53.9 \%$ of the sightings and was observed on all but one survey. The next most commonly sighted species was the white-crowned sparrow (Zonotrichia Zeucophrys) which accounted for just $14.7 \%$ of the sightings and was observed on seven of the 16 surveys.

\section{Iests of Homogeneous Detectability}

In only one of the 16 surveys conducted were 40 or more birds sighted. Included among these sightings were both individual birds and flocks of 
TABLE 8, Frequency of Occurence of the 18 BIrd Species Sighted

During the Course of 16 Line-Transect Surveys

\begin{tabular}{|c|c|c|c|c|}
\hline Common Name & Scientific Name & $\begin{array}{c}\text { Total } \\
\text { Count During } \\
\text { Surveys } \\
\end{array}$ & $\begin{array}{c}\text { Percent } \\
\text { of } \\
\text { Count } \\
\end{array}$ & $\begin{array}{c}\text { Number } \\
\text { of Surveys } \\
\text { Where } \\
\text { Observed } \\
\end{array}$ \\
\hline Dark-Eyed Junco & Junco hyemalis & 139 & 53.9 & 15 \\
\hline White-Crowned Sparrow & Zonotrichia Zeucophrys & 38 & 14.7 & 7 \\
\hline Horned Lark & Eremophila alpestris & 30 & 11.6 & 3 \\
\hline Mountain Chickadee & Pooms gombeli & 14 & 5.4 & 6 \\
\hline Sage Sparrow & Amphispiza belli & 7 & 2.7 & 5 \\
\hline Cassin's Finch & Carpodacus cassinii & 6 & 2,3 & 1 \\
\hline Mountain Bluebird & Sialia cumpoides & 5 & 1,9 & 2 \\
\hline Clark's Nutcracker & Nhucifraga columbiana & 3 & 1.2 & 2 \\
\hline Song Sparrow & Melospiza mezodia & 2 & 0.8 & 1 \\
\hline Western Meadowlark & Stumella neglecta & 2 & 0.8 & 2 \\
\hline Scrub Jay & Aphelocoma coemulescens & 2 & 0.8 & 2 \\
\hline Black-Billed Magpie & Pica pica & 2 & 0.8 & 1 \\
\hline Loggerhead Shrike & Lanius Iudovicianus & 2 & 0.8 & 2 \\
\hline Sharp-Shinned Hawk & Accipiter striatus & 2 & 0.8 & 2 \\
\hline Mourning Dove & Zenaidura macroura & 1 & 0.4 & 1 \\
\hline Rob in & Turdus migratorius & 1 & 0.4 & 1 \\
\hline Ha iry Woodpecker & Dendrocopos vilzosus & 1 & 0.4 & 1 \\
\hline Pinyon Jay & Gymnorhinus cyanocephalus & 1 & 0.4 & 1 \\
\hline & Totals & 258 & $\overline{100 \%}$ & $\overline{55}$ \\
\hline
\end{tabular}


Individuals, a common occurrence during the fall migratory season. Burnham et al. (1978) recommends that at least 40 sightings of individual birds be used as the basis for estimates of a detection function using Fourier serles analysis. The lack of sufficient sightings required other means of analyses be used to investigate detectablility during the surveys.

Using analysis of variance techniques for a Latin-square design, the existence of temporal and spatlal effects on mean detection distance were tested. Sighting distance and angle measurements were converted to perpendicular distances, then log-transformed before analysis. Sightings from flocks and extreme observations $(\geq 200 \mathrm{~m})$ were excluded to minimize problems of heteroschedasticity and lack of independence (Appendix $C$ ).

Results of the analyses of total sightings from all species (Table 9) and sightings of $J$. hyemazis (Table 10) indicate that the mean perpendicular sighting distance was not constant during all surveys. Significance of the lack-of-fit hypotheses suggests that the relationships between detectlon distance and the effects of dally differences, site differences and survey times are not simply additive. Further examination of mean perpendicular sighting distances for each survey indicate no consistent pattern in mean distances between the four sites or between survey times. Hence the changes in mean detection distance cannot be attributed to a single effect. The consequence is that the survey data cannot be pooled across censuses to increase sample sizes and permitting estimates of the detection function by means of Fourier analysis.

An additional consequence of the findings of significant differences in detection distances is that the bird counts cannot be strictly used in valid comparisons of avlfauna abundance. To correctly interpret avifauna censuses, counts from the surveys would need to be adjusted for the probablilities of detection which uniquely existed during the time of the surveys. The extent of such adjustments and their effect on comparisons of avifauna abundance cannot be assessed, however, without their estimation. It appears Iine-transects considerably longer than $1.5 \mathrm{~km}$ would be 
TABLE 9. Analysis of Variance Table for Log-Transformed Perpendicular Sighting Distances Based on Observations from All Avifauna Species

\begin{tabular}{|c|c|c|c|c|}
\hline Source & D.F, & M.S. & $\mathrm{F}$ & $\alpha$ \\
\hline Total (corrected) & 206 & & & \\
\hline Between sites & 3 & 2.716 & 3.247 & 0.023 \\
\hline Between days & 3 & 2.538 & 3.034 & 0.031 \\
\hline Between survey times & 3 & 2.184 & 2.611 & 0.053 \\
\hline Lack-of-fit & 5 & 1.828 & 2.186 & 0.058 \\
\hline Error & 192 & 0.837 & & \\
\hline
\end{tabular}

TABLE 10. Analysis of Variance Table for Log-Transformed Perpendicular Sighting Distances Based on Observations of $J$. hyemalis

\begin{tabular}{lrrrrr}
\multicolumn{1}{c}{ Source } & D.F. & M.S. & & $\alpha$ \\
\cline { 1 - 1 } Total (corrected) & 116 & & & & \\
Between sites & 3 & 1.283 & 1.620 & 0.189 \\
Between days & 3 & 3.816 & 4.819 & 0.004 \\
Between survey times & 3 & 1.910 & 2.412 & 0.071 \\
Lack-of-fit & 5 & 2.544 & 3.212 & 0.010 \\
Error & 102 & 0.792 & &
\end{tabular}


necessary to assure sufficlent observations to estimate avifauna abundance during the fall season by means of Fourier series analysis or other avallable methods.

\section{Varlabllty in Avifauna Abundance}

The lack of sufficient bird sightings per survey prevented the estimation of bird densities and associated sampling errors of such estimates by means of Fourler series analysis (Burnham et al. 1978). Without density estimates and their varlances, the between-site variance in avifauna abundance could not be properly computed.

However, using the Latin-square survey scheme, the variances associated with the bird counts (Table 11) from the 16 surveys were approximated. Scheffé (1959: p. 153) gives expressions for the expected values of the mean squares for an analysis of variance of a Latin square design and these expressions were used to estimate variance components. The mean number of birds sighted per survey was 16.1 individuals. Based on the results of the analysis of varlance (Table 12), sampling error was estimated to be 18.08 and the variance in avifauna abundance between sites was estimated at 104.04. Hence a 5-fold difference in the sizes of the sampling error and the between-sites variance was observed. The F-test for the main effect of sites indicates that the variance between sites is indeed significantly different $(\alpha<0.01)$ from zero.

Using just the counts of $J$. hyemalis the most abundant species observed on the surveys, the mean number observed per survey was 8.7 with an estimated sampling error of 26.15 and an estimated between-site variance of 62.02. Again the between-site variance was found to be significantly different $(\alpha<0.01)$ from zero and was 2.4-fold larger than the sampling error (Table 13). 
TABLE 11. Total Bird Counts and Numbers of $J$. hyemalis (in parentheses) Sighted During the 16 Line-Transect Surveys. Data are presented according to study sites (D1, D2, R1, R2), census periods during the day and date.

\begin{tabular}{|c|c|c|c|c|}
\hline \multirow[b]{2}{*}{ Date } & \multicolumn{4}{|c|}{ Census Period } \\
\hline & $8: 00-9: 15 \mathrm{am}$ & $9: 45-11: 15 \mathrm{am}$ & $11: 45-1: 15 \mathrm{pm}$ & $1: 45-3: 00 \mathrm{pm}$ \\
\hline 16 Oct 81 & $R 1-16(8)$ & $R 2-8(1)$ & $01-37$ (9) & $\mathrm{D} 2-0(0)$ \\
\hline 17 Oct 81 & $01-48(35)$ & $02-15(5)$ & $R 1-23(15)$ & $R 2-14(7)$ \\
\hline 18 Oct 81 & $R 2-14(1)$ & $D 1-26(24)$ & $D 2-9(2)$ & $R 1-6(5)$ \\
\hline 20 Oct 81 & $02-10(3)$ & $R 1-13(11)$ & $R 2-6(1)$ & $D 1-13(12)$ \\
\hline
\end{tabular}

TABLE 12. Analysis of Variance Table for the Latin Square Design Used in the Analysis of Total Bird Counts

\begin{tabular}{|c|c|c|c|c|c|c|}
\hline Source & D.F. & M.S. & $E\left(M . S_{.}\right)$ & $\hat{\sigma}^{2}$ & F-statistic & $\alpha$-Level \\
\hline Total (corrected) & 15 & & & & & \\
\hline Between sites & 3 & 418.25 & $\sigma^{2}+4 \sigma_{s}^{2}$ & 100.04 & 23.129 & 0.001 \\
\hline Between days & 3 & 155.75 & $\sigma^{2}+4 \sigma_{D}^{2}$ & 34.42 & 8.613 & 0.014 \\
\hline Between survey times & 3 & 138.42 & $\sigma^{2}+4 \sigma_{T}^{2}$ & 30.09 & 7.654 & 0.018 \\
\hline Error & 6 & 18.08 & $\sigma^{2}$ & 18.08 & & \\
\hline
\end{tabular}

TABLE 13. Analysis of Variance Table for the Latin Square Design Used in the Analysis of Sighting Counts of $J$. hyemalis

\begin{tabular}{|c|c|c|c|c|c|c|}
\hline Source & D.F. & M.S. & $E(M . S)$. & $\hat{\sigma}^{2}$ & E-statistic & $\alpha-$ Level \\
\hline Total (corrected) & 15 & & & & & \\
\hline Between sites & 3 & 274.23 & $\sigma^{2}+4 \sigma_{s}^{2}$ & 62.02 & 10.488 & 0.008 \\
\hline Between days & 3 & 90.90 & $\sigma^{2}+4 \sigma_{D}^{2}$ & 16.19 & 3.476 & 0.091 \\
\hline Between survey times & 3 & 30.40 & $\sigma^{2}+4 \sigma_{T}^{2}$ & 1.06 & 1.163 & 0.399 \\
\hline Error & 6 & 26.15 & $\sigma^{2}$ & 26.15 & & \\
\hline
\end{tabular}


The estimates of the variance components resulting from the analys is of variance tables were based on the assumption that the model for a Latin-square design was valid. When interactions exist, the estimates of variances are biased (Scheffe 1959:p. 154-158) and alternative expressions for the expected mean squares are appropriate (Scheffé 1959:p. 304-312). The fact that interactions were found significant $(0.10>\alpha>0.01)$ in the analysis of mean detection distances may also imply that interactions may exist in the relationship between bird counts and the effects of differences between plots, days and times of surveys. However, possible interaction terms cannot be estimated from the current survey scheme, and consequently, any appropriate adjustments in variance estimates are not possible.

Review of the analysls of varlance Tables 12 and 13, Indicate significant $(\alpha<0.05)$ main effects also existed for between days and between survey times for total bird counts. Regardless of possible causes, temporal effects appear to significantly influence $(\alpha<0.05)$ blrd counts and the use of blocking, as employed in the Latin-square design, can substantially reduce experimental error. When blocking for days and survey times are taken into account the mean square error (MSE) for total bird counts is computed to be 18.08 (Table 12), however, when the same data is analyzed ignoring the blocking the MSE is 82.53. In Phase 11 research of this project to develop monitoring designs, the properties of blocking will be used in the design of survey schemes.

\section{Cost Function for the Surveys}

The levels of effort used to locate and establish the avifauna transect-lines and to conduct the surveys were recorded during Fall 1981 . These data formed the basis of a cost function descrlbing the collection costs for the avifauna census data. Cost function was constructed based on four components, these were: 
1. fixed costs,

2. costs of locating suitable avifauna survey sites,

3. costs of equipment and labor to establish the line-transects,

4. costs of conducting the avifauna surveys.

The function may be written as:

$$
\cos T=A+0.5 B X+(C+0.33 B) X Y+D B\left[\frac{X Y}{6}\right]
$$

where $A=$ fixed costs of initiating an avifauna survey program,

$B=$ cost of 1-days support. labor and transportation for a 2-person field crew.

$\mathrm{C}=$ equipment costs of marking $1-\mathrm{km}$ of line transect.

$D=$ number of days surveys are to be repeated,

$x=$ number of avifauna survey sites established,

$y=$ length of IIne-transects in $\mathrm{km}$,

and where [] denotes the smallest integer that is greater than or equal to the expression.

The cost function is based on several simplifying assumptions including that the establishment costs are directly proportional to Iine-transect length. Another major assumption is that labor costs for conducting the surveys is proportional to the total distance of Iine-transects established. One 2-person fleld crew is considered to be capable of conducting approximately $6-\mathrm{km}$ of IIne-transect per day including necessary travel based on observations from the Fall 1981 fleld work. An additional 2-person crew is deemed necessary for every $6-\mathrm{km}$ of I ine-transect established. 
The additional sampling perlods planned for spring and summer of 1982 will be used to refine and validate the cost function for avifauna surveys. As written, the equation is a step function, and to be used in future calculations to optimize allocation of monitoring efforts, an additional approximation using a continuous function will be needed. Continuous functions will be developed as part of Phase 11 research. 


\section{DISCUSSION}

The small mammal census grids and the avifauna IIne-transects were all located in what may be considered as "equally sultable sites". The gulch terrains were selected for the location of the censuses because they represented areas of potentlal impact with future development of oil shale. The gulch terrains possessed many of the qualities deemed necessary to establish viable control and treatment areas for quantitative impact assessment.

An important quality in assessing the utility of small mammal and avifauna censuses was the extent of the natural varlability in faunal abundance in gulch environments. The more homogeneous the environment, and the faunal populations residing in the habitats, the greater is the probability that impacts will be detected if they occur. For this reason, a single vegetation type was selected for the placement of all sites, the sagebrush-greasewood communlty. Study sites were selected as similar as possible with the hope that by purposely selecting such sites, the variablility in faunal abundance would be minlmized. Other forms of site selection, such as the random sampling of locations would have resulted in necessarlly larger variances. In the context of experimental design or survey sampling theory, the sagebrush-greasewood community would be considered a "block" or "sampling strata" selected for the homogeneity of the elements within the category.

With sites selected for unlformity, the purpose of separately estimating the variance components for sampling error and plot-to-plot variance was to determine the relative contributions of observer error and environmental heterogeneity to the overall variance in field sampling. Estimation of the plot-to-plot variance in abundance also permited an evaluation of the slze of the variance in the response variable being monitored. 
During Fall 1981, the mean abundance of $E$. minimus was estimated at 19.1 per 1-ha plot; however, the varlance in abundance between plots was estimated at 85.93. Similarlly, for $P$, manicuzatus mean abundance was estimated at 50.5 individuals per 1-ha plot and with a plot-to-plot varlance in abundance of 214.61. Both specles are characterized by considerable heterogeneity in abundance. Examination of the bird count data from the line-transects show similar results. Mean count per survey was 16.1 birds but with a between site varlance of 100.04. Sampling error in all these cases was considerably smaller than the between plot variance.

Two general concluslons can be made from these results. FIrst, it appears that monitoring efforts should not be concentrated to a few plots where animal abundance is intensely characterized. The heterogeneity in abundance suggests monitoring efforts should be placed at the replicate plot level and not at sampling Individual animals. The specific allocations of efforts to optimize monitoring efforts for finite resources is the subject of Phase 11 research on this project. Secondly, because of the large heterogenelty in abundance, use of a few representative plots allocated to the varlous habitat types present in the Piceance Basin may result in quite misleading conclusions. Even such simple aspects as the relationship between abundance or faunal composition and habitat type may be misconstrued if study plots are not repllicated.

Among the four replicate avifauna Iine-transects (ail within the same sagebrush-greasewood community), the proportion of blrd counts attributable to the dark-eyed junco ( $J$. hyemalis) differed significantly between transects $\left(X_{3}^{2}=33.286, \alpha<0.01\right)$. Similarly, the ratio of $P$. maniculatus to E. minimus on the six small mammal plots was estimated at $\hat{R}=2.65$ but with a varlance estimate of $\hat{\operatorname{Var}}(\hat{R})=18.45$. The observed varlance in the ratio of the two species was found too large with even a sample of six plots to permit preclse estimates of the relative composition of the two species. 
Statistical inferences as to differences in faunal abundance or species composition between habitat types, between control and impacted areas, or between perlods of time requires replication at the population level. The varlance estimates obtained during the Fall 1981 field sampling will provide the basis to determine the levels of replication needed to detect reasonable changes in abundance the possible result of impacts. 
46 


\section{SUMMARY}

Censuses were conducted during October 1981 to estimate the fall abundance of small mammals and avifauna on replicate plots in the vicintiy of Federal Tract C-a (Rio Blanco 0il Shale Company). The objectives of the fall censuses were to evaluate alternative census techniques, test assumptions vital to the use of indices and abundance estimators, determine cost-functions associated with monitoring efforts, and estimate variance components needed to devise optimal monitoring designs. Analyses of the fall census data on small mammal abundance indicate:

- Coefficients of variation (CV) were 40-50\% for estimates of small mammal abundance, suggesting that suitable monltoring designs are possible.

- Average deer mice abundance (Peromyscus maniculatus) on a 1-ha plot in sagebrush-greasewood communities was 50.5 animals. Plot-to-plot varlance was 214.6, sampling error 2.1. This 100-fold difference in variance components strongly suggests "extensive" rather than "intenslve" sampling will be appropriate in designing the assessment studies.

- The small sampling error resulted from 3-day capture rates in excess of $90 \%$, suggesting seasonal patterns in catchability must be considered in al locating monitoring efforts.

- Capture probabilities were not significantly different $(\alpha>0.10)$ for replicate populations censused simultaneously during removal sampling, suggesting that indices of abundance rather than absolute abundance procedures may be appropriate with subsequent reductions in monitoring costs. 
- The topography of the Piceance Basin seems sultable for using controltreatment pairing (CTP) designs for impact assessments; designs which have been demonstrated to reduce the size of monitoring programs.

- The mark-removal census procedure employed during the fall period appears to be consistent with the objectives of both fate and effects monitoring, since the census procedure provided both valid abundance estimates and specimens for chemical analysis.

- Chi-square tests indicated significant differences in the relative composition of $P$. maniculatus and $E$. minimus on replicate plots in similar terrain and habitat type suggesting the use of "representative" plots may not provide adequate descriptions of even specles composition of small mammal communities.

Analyses of the fall census data on avifaunal populations indicate:

- The fall season may be an inapproprlate period to census avifauna because of the fall migratory behavior of bird specles and its affect on sampling precision.

- The mean number of birds sighted per 1.5-km Ilne-transect survey was 16.1, the between-sites variance in bird counts was computed to be 100.04 and the sampling error 18.08. This is a 5-fold difference in the size of variance components.

- When the avifauna survey design accounted for the effects of temporal detectability changes, the $\mathrm{CV}$ was $26 \%$ for the survey data, however, when blocking for possible temporal effects was ignored the $\mathrm{CV}$ for avifauna data increased to $56 \%$. Results suggest that statistical blocking should be used in avifauna monitoring programs. 
- The average sighting distance when birds were first detected changed significantly $(\alpha<0.05)$ from day to day, from replicate-to-replicate, and within time of day. suggesting both spatial and temporal effects on detectability. As a consequence it appears that absolute abundance estimators may be needed to provide valid comparisons in avifauna monitoring programs.

- Fall avifauna abundance appears to be too low to permit absolute abundance estimates of bird densities even when 1.5-km line-transects are traversed, suggesting probably the fall period should be omitted in monitoring schemes.

- Among replicate IIne-transects in similar terrain and habitat type, significant $(\alpha<0.05)$ differences in avifauna composition were observed. 


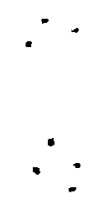


Burnham, K. P., D. R. Anderson, and J. L. Laake. 1980. "Estimation of Density from Line Transect Sampling of Biological Populations." Wild!. Monograph 72:1-202.

Chapman, D. G. 1951. "Some Properties of Hypergeometric Distribution with Applications to Zoological Census." Univ. Calif. Publ. Stat. 1:131-160.

Eberhardt, L. L. 1976. "Quantitative Ecology and Impact Assessment." J. Envir. Manage. 4:27-70.

Eberhardt, L. L. 1978. "Appraising Variability in Population Studies." J. Wildl. Manage. 42:207-238.

Gentry, J. B., R. B. Golley and J. T. McGinnis. 1966. "Effect of Weather on Captures of Small Mammals." Amer. Midl. Nat. 75(2):526-530.

Getz, L. L. 1961. "Response of Small Mammals to Live-Traps and Weather Conditions." Amer. Midl. Nat. 66(1):160-169.

Green, R. H, 1979. Sampling Design and Statistlcal Methods for Environmental Biologists. John Wiley and Sons, Inc., New York.

Klonghan, E. D. 1955. "Factors Influencing the Fall Roadside Pheasant

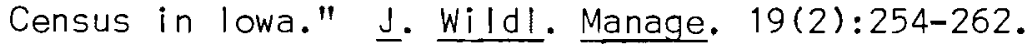

McKenzie, D. H., E. M. Arnold, J. R. Skalski, D. H. Fickeisen and K. S. Baker. 1979. Quantitative Assessment of Aquatic Impacts of Power Plants. NUREG/CR-0631, PNL-2891, Pacific Northwest Laboratory, Richland, Washington.

Mystkowska, E. T., and J. Sidorowicz. 1961. "Influence of the Weather on Captures of Micro-Mammalia. II. Insectivora." Acta Theriologica $5: 263-273$.

Otis, D. L., K. P. Burnham, G. C. White, and D. R, Anderson. 1978. "Statistical Inference from Capture Data on Closed Animal Populations." Wildl. Monogr. 62:1-135.

Perry, H. R., Jr., G. B. Pardue, F. S. Barkalow and R. J. Monroe. 1977. "Factors Affecting Trap Response of the Gray Squirrel." $\underline{J}$. Wildl. Manage. $41(1): 135-143$.

Scheffé, H. 1959. The Analysis of Variance. John Wiley and Sons, Inc, New York.

Seber, G. A. F. 1973. The Estimation of Animal Abundance and Related Parameters. Charles Griffin and Co. Limited, London. 
Seber, G. A. F., and J. F. Whale. 1970. "The Removal Method for Two and Three Samples." Biometrics 26:393-400.

Skaiski, J. R. and D. H. McKenzie. 1982. "A Design for Aquatic Monitoring Programs." J. Envir. Manage. (in press).

Skalski, J. R. and D. S. Robson. 1979. "Tests of Homogeneity and Goodnessof-Fit to a Truncated Geometric Model for Removal Sampling." In Sampling. Biological Populations, eds. R. M. Cormack, G. P. Patel and D. S. Robson, pp. 283-313. International Co-operative Publishing House, Fairland, Maryland.

Skalski, J. R, and D. S, Robson. 1982, "A Mark and Removal Field Procedure for Estimating Population Abundance." $\underline{J}$. Wildl. Manage. (in press).

Skalski, J.R., D. S. Robson and M. A. Simmons. 1982. "Comparative Census Procedures Using Single Mark-Recapture Methods." Ecology (submitted).

Zippin, C. 1956. "An Evaluation of the Removal Method of Estimating Animal Populations." Biometrics 12:163-189.

Zippin, C. 1958. "The Removal Method of Population Estimation." J. Wildl. Manage. 22:32-90. 
APPENDIX A

DATA MATRICES FROM SMALL MAMMAL CENSUSES 
APPENDIX A

\section{DATA MATRICES FROM SMALL MAMMAL CENSUSES}

Data matrlces from the mark-removal field procedures for $P$. maniculatus and E. minimus at the six study plots in the vicinity of Tract $\mathrm{C}$-a are presented in the following 12 Tables.

A. 1 
TABLE A.1. Summary of Capture Data for Deer Mice

(Peromyscus maniculatus) at site C1

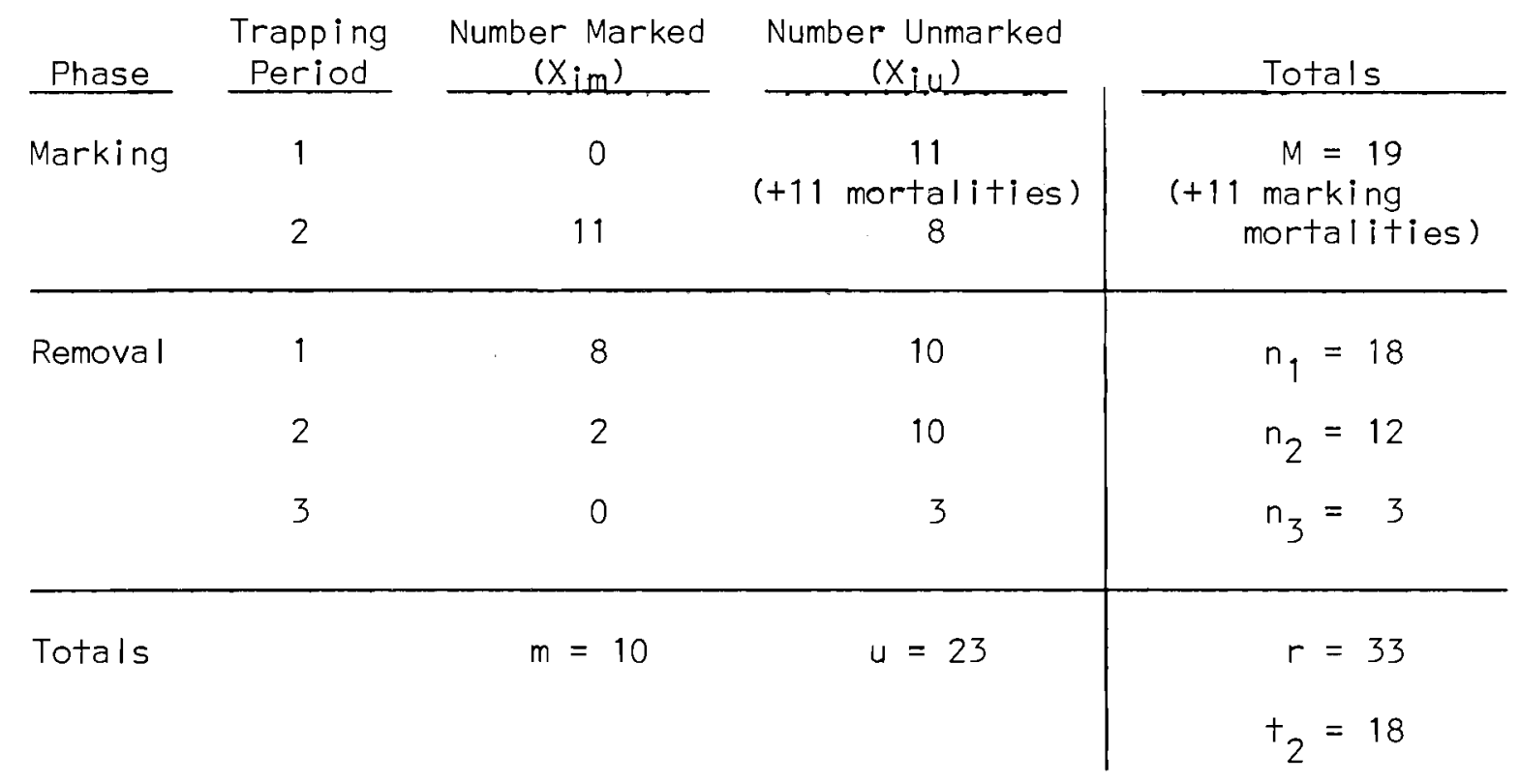

TABLE A.2. Summary of Capture Data for Least Chipmunks (Eutomius minimus) at Site $\mathrm{C1}$

\begin{tabular}{|c|c|c|c|c|}
\hline Phase & $\begin{array}{c}\text { Trapping } \\
\text { Period } \\
\end{array}$ & $\begin{array}{c}\text { Number Marked } \\
\left(X_{i m}\right)\end{array}$ & $\begin{array}{c}\text { Number Unmarked } \\
\left(x_{i \text { iu }}\right)\end{array}$ & Totals \\
\hline \multirow[t]{2}{*}{ Marking } & 1 & 0 & 1 & $M=6$ \\
\hline & 2 & 0 & 5 & \\
\hline \multirow[t]{3}{*}{ Removal } & 1 & 4 & 2 & $n_{1}=6$ \\
\hline & 2 & 0 & 3 & $n_{2}=3$ \\
\hline & 3 & 0 & 0 & $n_{3}=0$ \\
\hline Totals & & $m=4$ & $u=5$ & $\begin{aligned} r & =9 \\
t_{2} & =3\end{aligned}$ \\
\hline
\end{tabular}


TABLE A.3. Summary of Capture Data for Deer Mice

(Peromyscus maniculatus) at site $\mathrm{C} 2$

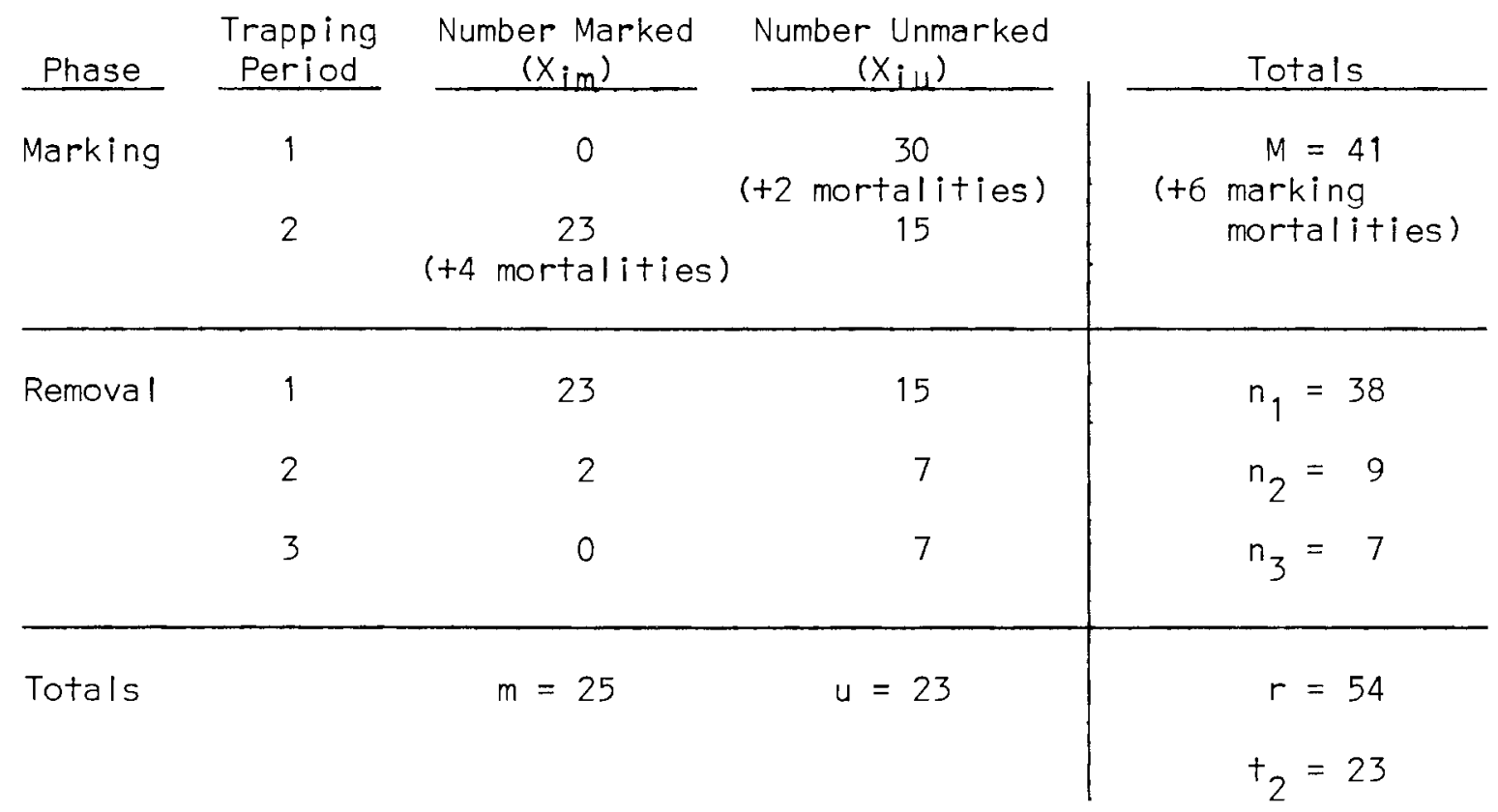

TABLE A.4. Summary of Capture Data for Least Chipmunks (Eutomius minimus) at Site $\mathrm{C} 2$

\begin{tabular}{|c|c|c|c|c|}
\hline Phase & $\begin{array}{l}\text { Trapping } \\
\text { Period } \\
\end{array}$ & $\begin{array}{c}\text { Number Marked } \\
\left(X_{i m}\right)\end{array}$ & $\begin{array}{c}\text { Number Unmarked } \\
\left(X_{i_{u}}\right)\end{array}$ & Totals \\
\hline \multirow[t]{2}{*}{ Marking } & 1 & 0 & 0 & $M=1$ \\
\hline & 2 & 0 & 1 & \\
\hline \multirow[t]{3}{*}{ Removal } & 1 & 1 & 2 & $n_{1}=3$ \\
\hline & 2 & 0 & 1 & $n_{2}=1$ \\
\hline & 3 & 0 & 0 & $n_{3}=0$ \\
\hline Totals & & $m=1$ & $u=3$ & $\begin{aligned} r & =4 \\
t_{2} & =1\end{aligned}$ \\
\hline
\end{tabular}


TABLE A.5. Summary of Capture Data for Deer Mice (Peromyscus maniculatus) at site D1

\begin{tabular}{|c|c|c|c|c|}
\hline Phase & $\begin{array}{l}\text { Trapping } \\
\text { Period } \\
\end{array}$ & $\begin{array}{c}\text { Number Marked } \\
\left(X_{\mathrm{im}}\right)\end{array}$ & $\begin{array}{c}\text { Number Unmarked } \\
\left(X_{j_{u}}\right)\end{array}$ & Totals \\
\hline Marking & $\begin{array}{l}1 \\
2\end{array}$ & $\begin{array}{c}0 \\
6 \\
(+7 \text { mortalities })\end{array}$ & $\begin{array}{c}16 \\
6 \\
(+1 \text { mortality })\end{array}$ & $\begin{array}{c}M=15 \\
(+8 \text { marking } \\
\text { mortalities })\end{array}$ \\
\hline \multirow[t]{3}{*}{ Removal } & 1 & 12 & 16 & $n_{1}=28$ \\
\hline & 2 & 2 & 4 & $n_{2}=6$ \\
\hline & 3 & 0 & 5 & $n_{3}=5$ \\
\hline Totals & & $m=14$ & $u=25$ & $\begin{aligned} r & =39 \\
t_{2} & =16\end{aligned}$ \\
\hline
\end{tabular}

TABLE A.6. Summary of Capture Data for Least Chipmunks (Eutomius minimus) at Cite D1

\begin{tabular}{|c|c|c|c|c|}
\hline Phase & $\begin{array}{l}\text { Trapping } \\
\text { Period } \\
\end{array}$ & $\begin{array}{c}\text { Number Marked } \\
\left(X_{i m}\right) \\
\end{array}$ & $\begin{array}{c}\text { Number Unmarked } \\
\left(x_{i_{u}}\right)\end{array}$ & Totals \\
\hline \multirow[t]{2}{*}{ Marking } & 1 & 0 & 10 & $M=17$ \\
\hline & 2 & 10 & 7 & \\
\hline \multirow[t]{3}{*}{ Removal } & 1 & 13 & 9 & $n_{1}=22$ \\
\hline & 2 & 3 & 1 & $n_{2}=4$ \\
\hline & 3 & 0 & 2 & $n_{3}=2$ \\
\hline Totals & & $m=16$ & $u=12$ & $\begin{aligned} r & =28 \\
t_{2} & =8\end{aligned}$ \\
\hline
\end{tabular}


TABLE A.7. Summary of Capture Data for Deer Mice

(Peromyscus maniculatus) at site D2

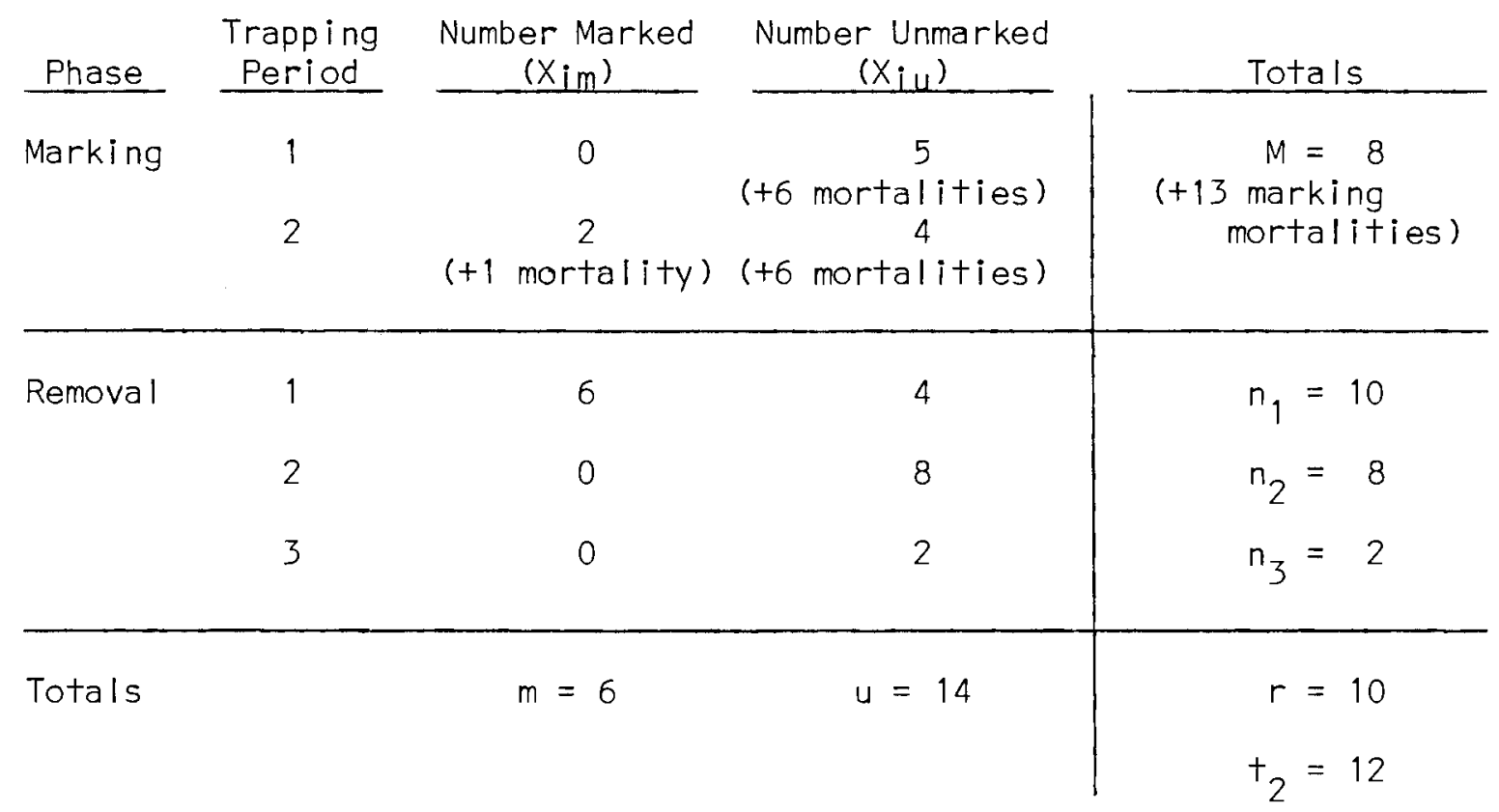

TABLE A.8. Summary of Capture Data for Least Chipmunks (Eutcomius minimus) at site D2

\begin{tabular}{|c|c|c|c|c|}
\hline Phase & $\begin{array}{l}\text { Trapping } \\
\text { Period } \\
\end{array}$ & $\begin{array}{c}\text { Number Marked } \\
\left(X_{i m}\right) \\
\end{array}$ & $\begin{array}{c}\text { Number Unmarked } \\
\left(x_{i \cup}\right)\end{array}$ & Totals \\
\hline \multirow[t]{2}{*}{ Marking } & 1 & 0 & 6 & $M=12$ \\
\hline & 2 & 6 & 6 & \\
\hline \multirow[t]{3}{*}{ Removal } & 1 & 12 & 4 & $n_{1}=16$ \\
\hline & 2 & 0 & 0 & $n_{2}=0$ \\
\hline & 3 & 0 & 2 & $n_{3}=2$ \\
\hline Totals & & $m=12$ & $u=6$ & $\begin{aligned} r & =18 \\
t_{2} & =4\end{aligned}$ \\
\hline
\end{tabular}


TABLE A.9. Summary of Capture Data for Deer Mice

(Peromyscus maniculatus) at Site R1

\begin{tabular}{|c|c|c|c|c|}
\hline Phase & $\begin{array}{l}\text { Trapping } \\
\text { Period } \\
\end{array}$ & $\begin{array}{c}\text { Number Marked } \\
\left(X_{i m}\right)\end{array}$ & $\begin{array}{c}\text { Number Unmarked } \\
\left(X_{i U}\right)\end{array}$ & Totals \\
\hline Marking & $\begin{array}{l}1 \\
2\end{array}$ & $\begin{array}{c}0 \\
4 \\
(+2 \text { mortal ities }\end{array}$ & $\begin{array}{c}6 \\
(+5 \text { mortalities }) \\
4 \\
\text { (+1 mortality) }\end{array}$ & $\begin{array}{c}M=8 \\
(+8 \text { marking } \\
\text { mortalities })\end{array}$ \\
\hline \multirow[t]{3}{*}{ Removal } & 1 & 4 & 9 & $n_{1}=13$ \\
\hline & 2 & 0 & 6 & $n_{2}=6$ \\
\hline & 3 & 0 & 3 & $n_{3}=3$ \\
\hline Totals & & $m=4$ & $u=18$ & $\begin{aligned} r & =22 \\
t_{2} & =12\end{aligned}$ \\
\hline
\end{tabular}

TABLE A.10. Summary of Capture Data for Least Chipmunks

(Eutomius minimus) at site R1

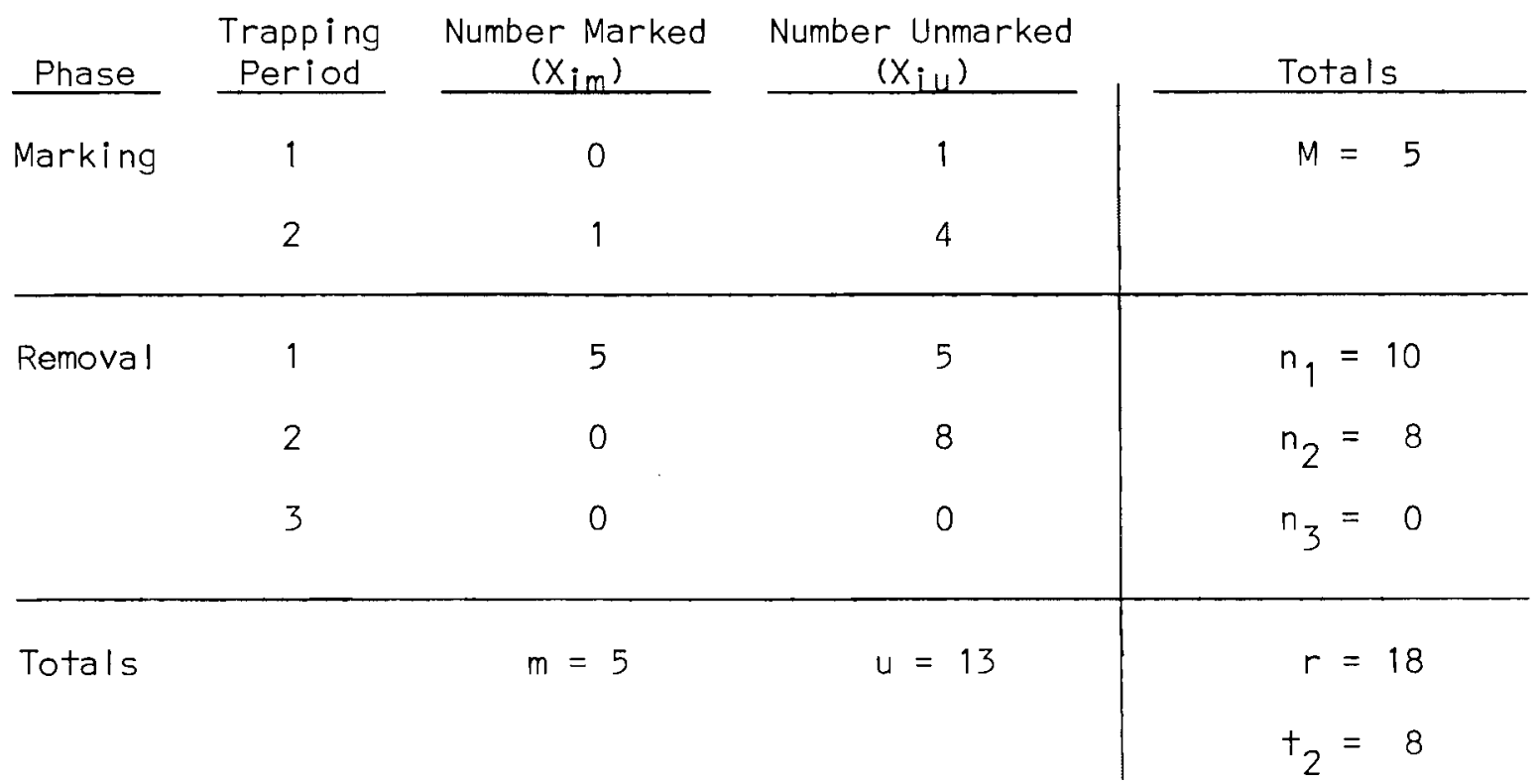

A. 6 
TABLE A.11. Summary of Capture Data for Deer Mice

(Peromyscus maniculatus) at Site R2

\begin{tabular}{|c|c|c|c|c|}
\hline Phase & $\begin{array}{l}\text { Trapping } \\
\text { Period } \\
\end{array}$ & $\begin{array}{c}\text { Number Marked } \\
\left(x_{\text {im }}\right) \\
\end{array}$ & $\begin{array}{c}\text { Number Unmarked } \\
\left(X_{i \mu}\right) \\
\end{array}$ & Totals \\
\hline Marking & $\begin{array}{l}1 \\
2\end{array}$ & $\begin{array}{c}0 \\
5 \\
(+2 \text { mortalities })\end{array}$ & $\begin{array}{c}8 \\
(+1 \text { mortal ity }) \\
2\end{array}$ & $\begin{array}{c}M=8 \\
(+3 \text { marking } \\
\text { mortalities })\end{array}$ \\
\hline \multirow[t]{3}{*}{ Removal } & 1 & 8 & 5 & $n_{1}=13$ \\
\hline & 2 & 0 & 5 & $n_{2}=5$ \\
\hline & 3 & 0 & 1 & $n_{3}=1$ \\
\hline Totals & & $m=8$ & $u=11$ & $\begin{aligned} r & =19 \\
t_{2} & =7\end{aligned}$ \\
\hline
\end{tabular}

TABLE A.12. Summary of Capture Data for Least Chipmunks (Eutamius minimus) at Site R2

\begin{tabular}{|c|c|c|c|c|}
\hline Phase & $\begin{array}{l}\text { Trapping } \\
\text { Period } \\
\end{array}$ & $\begin{array}{c}\text { Number Marked } \\
\left(X_{i m}\right) \\
\end{array}$ & $\begin{array}{c}\text { Number Unmarked } \\
\left(X_{i u}\right)\end{array}$ & Totals \\
\hline \multirow[t]{2}{*}{ Marking } & 1 & 0 & 5 & $M=15$ \\
\hline & 2 & 5 & $\begin{array}{c}10 \\
(+2 \text { mortalities })\end{array}$ & \\
\hline \multirow[t]{3}{*}{ Removal } & 1 & 11 & 12 & $n_{1}=23$ \\
\hline & 2 & 0 & 1 & $n_{2}=1$ \\
\hline & 3 & 0 & 1 & $n_{3}=1$ \\
\hline Totals & & $m=11$ & $u=14$ & $\begin{aligned} r & =23 \\
t_{2} & =3\end{aligned}$ \\
\hline
\end{tabular}




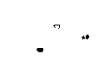

$\therefore$ 
APPENDIX B

ILLUSTRATION OF THE SMALL MAMMAL DATA ANALYSIS 


\section{ILLUSTRATION OF THE SMALL MAMMAL DATA ANALYSIS}

Using the mark-recapture data for E. minimus, the calculations for the statistical tests of assumptions and the method for population estimation are illustrated.

\section{IESTS OF HOMOGENEITY}

The chi-square test for homogeneous capture probabilities among replicate populations is calculated using the mark-recapture data from the table:

\section{POPULATIONS}

\begin{tabular}{c|c|c|c|c|c|c|c}
\multicolumn{1}{c}{$\mathrm{C1}$} \\
\cline { 2 - 7 } $\mathrm{M}-\mathrm{m}$ & 2 & 0 & 1 & 0 & 0 & 4 & 7 \\
\cline { 2 - 8 } & 5 & 3 & 12 & 6 & 13 & 14 & 53 \\
\hline $\mathrm{m}$ & 1 & 16 & 12 & 5 & 11 & 49 \\
\hline 11 & 4 & 29 & 18 & 18 & 29 & 109
\end{tabular}

The chi-square statistic for the $3 \times 6$ contingency table is $x_{10}^{2}=16.222$ with 10 degrees of freedom and has a statistical significance of $P\left(X_{10}^{2} \geq 16.222\right)=0.093$.

Alternatively, a test of homogeneity also can be computed from the removal data obtained from each study plot. A contingency table analysis can be performed using the removal data in the table: 
POPULATIONS

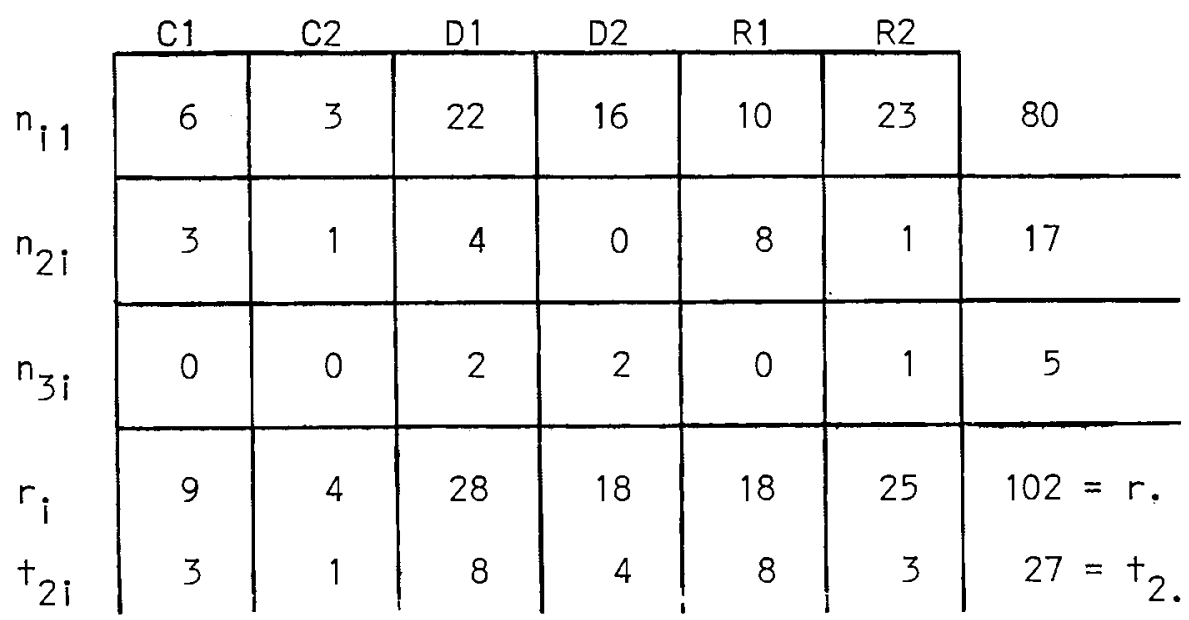

However, the Q-statistic (Skalski and Robson 1979) is a more powerful test of homogenelty when analyzing removal sampling data. The Q-statistic can be written as

$$
Q=\frac{\sum_{i=1}^{6} r_{i}\left(\bar{y}_{i}-\bar{y}_{j}\right)^{2}}{s_{y}{ }^{2}}
$$

and where $\bar{y}_{i}=t_{2 i} / r_{i}$

$$
\begin{aligned}
\bar{y} & =t_{2 .} / r . \\
S_{y}{ }^{2} & =\left[\sum_{i=1}^{r} y_{i}^{2}-\left(\sum_{i=1}^{r_{0}} y_{i}\right)^{2} / r .\right] /(r .-1) .
\end{aligned}
$$

The sufficient statistic $t_{2}$. can be interpreted as the total number of times $r$. animals escaped capture prior to being caught and $\bar{y}$. is the average number of escapes per animal. Hence, the Q-statistic compares the average "escape rate" for animals in the different populations. Based on the above table, $\bar{y}_{\cdot}=27 / 102$ and $S_{y} 2=0.2956$ resulting in $Q=4.037$. 
The Q-statistic is distributed as Chi-square with 5 degrees of freedom under the null hypothes Is and has significance level $P\left(X_{5}^{2} \geq 4.037\right)=0.544$.

\section{IESTS OF ASSUMPTIONS}

Pooling the data from the six replicate plots, the goodness-of-fit to a geometric model for removal sampling (Skalski and Robson 1979) can be tested $\left(n_{1}=80, n_{2}=17 . n_{3} .=5\right)$. The test statistic is

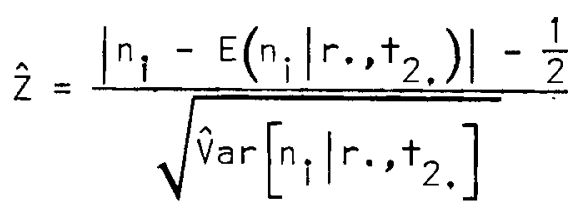

when

$$
\begin{aligned}
\hat{E}\left(n_{i} \mid r,, t_{2}\right) & =r A-\frac{A C}{\left(A B-C^{2}\right)}\left(t_{2},-r \cdot C\right) \\
\hat{\operatorname{Var}}\left(n_{i} \mid r ., t_{2}\right) & =r \cdot\left[A(1-A)-\frac{A^{2} C^{2}}{\left(A B-C^{2}\right)}\right]
\end{aligned}
$$

and where

$$
\begin{aligned}
& A=\frac{\hat{p}}{1-\hat{q}^{3}} \\
& B=\sum_{i=2}^{3}(i-1)^{2 \hat{q}^{i-1}} \\
& C=\left(\frac{\hat{q}}{\hat{p}}-\frac{3 \hat{q}^{3}}{1-\hat{q}^{3}}\right) .
\end{aligned}
$$

The estimated probability of capture, $p$, is obtained from the maximum likelihood estimators for the removal sampling model (ZIppin 1956, 1958) (see page 28 ). The capture probability is estimated to be $\hat{p}=0.767535$ 
$\left(r_{.}=102, t_{2}=27\right.$ ) resulting in $A=0.7773, B=0.4486$ and $C=0.2647$. The moments are subsequently estimated to be $\hat{E}\left[n_{1} \mid r_{.}=102,+2\right.$. = 27] = 79.2845 and $\hat{\operatorname{Var}}\left[n_{1} \mid r_{.}=102, t_{2} .=27\right]=2.1597$ with $n_{1}$ observed to be 80 . The Z-statistic is then computed to be $Z=0.1466$ with significance $P(Z>0.1466)=0.442$.

Using just the unmarked animais captured in each population during the 3-day removal sampling, the goodness-of-fit of unmarked animals can be tested from the data:

POPULATIONS

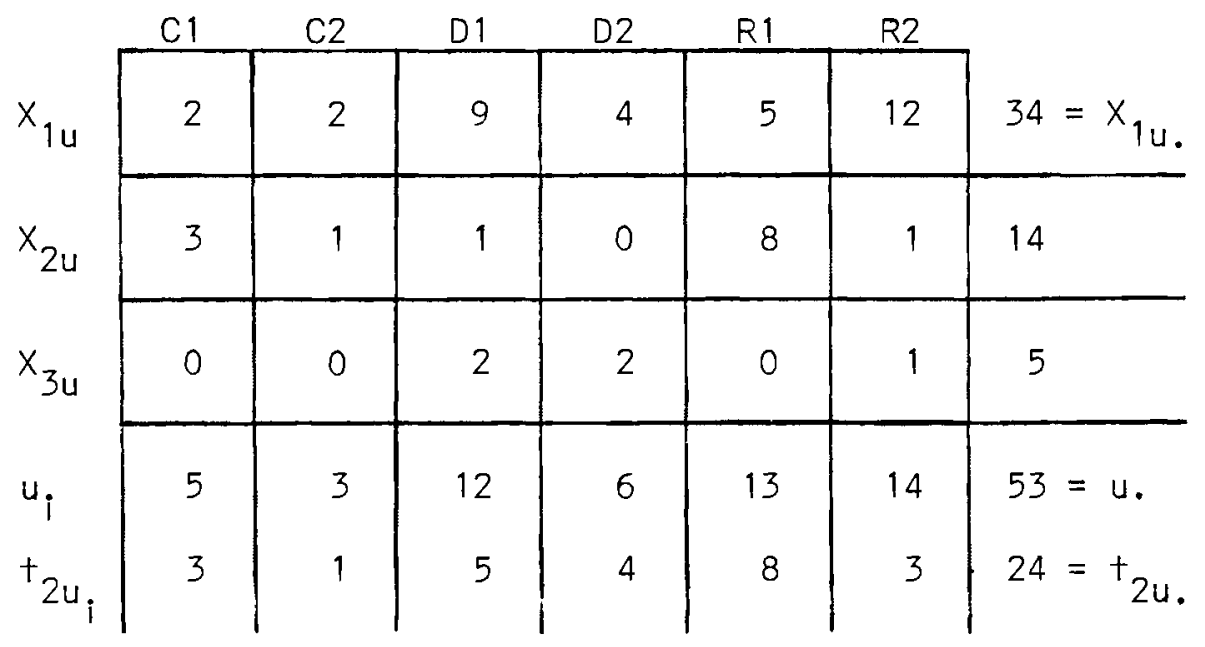

The capture probability for the unmarked animals is estimated to be $\hat{p}=0.60766\left(u_{e}=53 . t_{2 u_{0}}=24\right)$ and resulting in $A=0.6467, B=1.0081$ and $C=0.4528$. The moments are then estimated to be $\hat{E}\left[X_{1} u_{0} \mid u_{0}=53\right.$, $\left.t_{2 u_{0}}=24\right]=34.2761$ and $\hat{\operatorname{var}}\left[x_{1 u_{0}} \mid u_{0}=53 . t_{2 u}=24\right]=1.9374$ with an observed value of $x_{1 u}=34$. The resulting test statistic is $Z=-0.1609$ with a significance of $P(Z>-0.1609)=0.5639$.

The assumption of equal catchability of marked and unmarked animals is tested using the removal data in the contingency table: 
ANIMALS

\begin{tabular}{c|c|c|c}
\multicolumn{1}{c|}{} & \multicolumn{1}{c}{ MARKED } & \multicolumn{1}{c}{ UNMARKED } \\
\cline { 2 - 4 }$x_{1}$ & 46 & 34 & 80 \\
\cline { 2 - 4 }$x_{2}$ & 3 & 14 & 17 \\
\cline { 2 - 4 }$x_{3}$ & 0 & 5 & 5 \\
\cline { 2 - 4 }$r_{1}$ & 49 & 53 & $102=r$. \\
$t_{21}$ & 3 & 24 & $27=t_{2}$.
\end{tabular}

This test of equal catchability is performed identical to the calculations for the tests of homogeneity used earlier with removal sampling data. Based on the data, $\bar{y}=27 / 102, S_{y}{ }^{2}=0.2956$ and resulting in $Q=13.2100$ with significance level $P\left(X_{1}^{2}>13.2100\right)=0.0003$.

\section{ESTIMATION OF ABUNDANCE}

Results of the tests of assumptions suggest that abundance estimates should be based on removal data for unmarked animals. The estimator chosen estimates the unmarked animals in the populations, and to that are added the numbers of animals captured during the 2-day marking perlod. The resulting estimates should be robust to the presence of unequal capture rates for marked animals and handling mortalities. The estimator is presented on page 27 of this report.

From the goodness-of-fit test for unmarked animals during the 3-day removal sampling period, the probability of capture is estimated to be $\hat{p}=(1-\hat{q})=0.60766$. Population estimates for each plot are, therefore, 
based on the estimator $\hat{p}$, the numbers of unmarked animals caught $\left(u_{i}=5\right.$, $3,12,6,13$ and 14 for $i=1, \ldots, 6)$, and the total number of animals captured per plot during the 2-day Iive-trapping perlod $\left(M_{i}=6,1,17\right.$, 12,5 , and 15 for $(=1, \ldots, 6)$. For example, at plot $\mathrm{C} 1$ the E. minimus abundance is estimated to be $\hat{N}_{1}=6+5 /(1-0.06039)=11.3$. 
APPENDIX C

AVIFAUNA LINE-TRANSECT DATA 


\section{APPENDIX C}

\section{AVIFAUNA LINE-TRANSECT DATA}

The avifauna survey data are listed according to date $(16-18,20$ October 1981), site and time of day (morning surveys AM1 and AM2 and afternoon surveys PM1 and PM2). For each sighting, bird species and sighting distance $(m)$ and angle are recorded. Only those observations used for analyses in this report are presented. Sightings from flocks of birds and extreme observations $(>200 \mathrm{~m}$ ) were excluded to minimize problems of heteroschedasticity and lack of independence. Numeric codes associated with the various avifauna species are as follows:

$\begin{array}{ll}1 & \text { white-crowned sparrow } \\ 2 & \text { sage sparrow } \\ 3 & \text { song sparrow } \\ 4 & \text { dark-eyed junco } \\ 5 & \text { mountain chickadee } \\ 6 & \text { Cassin's finch } \\ 7 & \text { mourning dove } \\ 8 & \text { horned lark } \\ 9 & \text { western meadowlark } \\ 10 & \text { robin } \\ 11 & \text { mountain bluebird } \\ 12 & \text { Clark's woodpecker } \\ 13 & \text { hairy woodpecker } \\ 14 & \text { scrub jay } \\ 15 & \text { pinyon jay } \\ 16 & \text { black-billed magpie } \\ 17 & \text { loggerhead shrike } \\ 18 & \text { sharp-skinned hawk }\end{array}$




\begin{tabular}{|c|c|c|c|c|c|}
\hline site & Date & Time & $\begin{array}{c}\text { Species } \\
\text { Code } \\
\end{array}$ & $\begin{array}{c}\text { Distance } \\
(m)\end{array}$ & $\begin{array}{c}\text { Angle } \\
\text { (Degrees) }\end{array}$ \\
\hline R1 & 101681 & AM 1 & 1 & 37.0 & 80 \\
\hline R 1 & 101681 & AM 1 & 4 & 16.0 & 40 \\
\hline R 1 & 101681 & ANI & 4 & 55.0 & 70 \\
\hline R1 & 101681 & AM 1 & 4 & 55.0 & 70 \\
\hline R 1 & 101681 & AM1 & 4 & 55.0 & 70 \\
\hline R1 & 101681 & AM 1 & 1 & 45.1 & 45 \\
\hline R1 & 101681 & AM1 & 4 & 16.5 & 55 \\
\hline R 1 & 101681 & $A M 1$ & 4 & 45.1 & 40 \\
\hline R1 & 101681 & AM 1 & 5 & 15.0 & 60 \\
\hline R1 & 101681 & AM 1 & 4 & 70.0 & 51 \\
\hline R 1 & 101681 & AM 1 & 4 & 49.0 & 88 \\
\hline R1 & 101681 & AM 1 & 4 & 15.0 & 62 \\
\hline R1 & 101681 & AM 1 & 10 & 59.0 & 84 \\
\hline R 1 & 101681 & AM1 & 12 & 190.0 & 54 \\
\hline R1 & 101681 & AM1 & 1 & 28.5 & 8 \\
\hline R1 & 101681 & AM 1 & 5 & 62.0 & 53 \\
\hline $\mathrm{R} 2$ & 101681 & AM2 & 5 & 34.0 & 54 \\
\hline R2 & 101681 & AM2 & 5 & 25.5 & 13 \\
\hline R 2 & 101681 & AM2 & 9 & 89.0 & 76 \\
\hline R2 & 101681 & AM2 & 4 & 32.0 & 90 \\
\hline R2 & 101681 & AM2 & 11 & 64.0 & 90 \\
\hline R2 & 101681 & AM2 & 11 & 37.0 & 90 \\
\hline R 2 & 101681 & AM2 & 11 & 33.0 & 90 \\
\hline R2 & 101681 & AM2 & 11 & 64.0 & 88 \\
\hline D1 & 101681 & PM1 1 & 4 & 7.5 & 57 \\
\hline D1 & 101681 & PM1 1 & 8 & 13.5 & 52 \\
\hline D 1 & 101681 & PM1 & 8 & 13.5 & 52 \\
\hline D 1 & 101681 & PM 1 & 8 & 17.0 & 112 \\
\hline 01 & 101681 & PM1 & 8 & 17.0 & 112 \\
\hline D 1 & 101681 & PM 1 & 8 & 17.0 & 112 \\
\hline D 1 & 101681 & PM 1 & 8 & 17.0 & 112 \\
\hline D1 & 101681 & PM1 1 & 8 & 17.0 & 112 \\
\hline D1 & 101681 & PM1 1 & 8 & 17.0 & 112 \\
\hline D1 & 101681 & PM 1 & 4 & 41.0 & 52 \\
\hline D 1 & 101681 & PA1 1 & 4 & 33.0 & 76 \\
\hline D1 & 101681 & PM1 & 4 & 16.0 & 45 \\
\hline D1 & 101681 & PM1 & 4 & 16.0 & 45 \\
\hline
\end{tabular}




\begin{tabular}{|c|c|c|c|c|c|}
\hline Site & Date & Time & $\begin{array}{c}\text { Species } \\
\text { Code } \\
\end{array}$ & $\begin{array}{c}\text { Distance } \\
(\mathrm{m}) \\
\end{array}$ & $\begin{array}{c}\text { Angle } \\
\text { (Degrees) } \\
\end{array}$ \\
\hline D1 & 101781 & AM 1 & 4 & 5.3 & 90 \\
\hline D 1 & 101781 & AM 1 & 4 & 5.3 & 90 \\
\hline D 1 & 101781 & AM1 & 4 & 65.0 & 10 \\
\hline D1 & 101781 & AM 1 & 4 & 39.0 & 2 \\
\hline D 1 & 101781 & AM 1 & 4 & 36.0 & 4 \\
\hline D 1 & 101781 & AM 1 & 4 & 37.0 & 10 \\
\hline D1 & 101781 & $A M 1$ & 4 & 45.0 & 22 \\
\hline D 1 & 101781 & AM 1 & 4 & 45.0 & 22 \\
\hline D1 & 101781 & $A M 1$ & 4 & 45.0 & 22 \\
\hline D1 & 101781 & AM 1 & 4 & 41.0 & 30 \\
\hline D 1 & 101781 & AM 1 & 4 & 41.0 & 30 \\
\hline D 1 & 101781 & AM 1 & 4 & 41.0 & 30 \\
\hline D 1 & 101781 & AM 1 & 4 & 29.8 & 50 \\
\hline D1 & 101781 & AM1 1 & 4 & 29.8 & 50 \\
\hline D 1 & 101781 & AM 1 & 4 & 29.8 & 50 \\
\hline D 1 & 101781 & AM1 & 4 & 29.8 & 50 \\
\hline D1 & 101781 & AM 1 & 4 & 29.8 & 50 \\
\hline D 1 & 101781 & $A M 1$ & 5 & 32.5 & 70 \\
\hline D 1 & 101781 & AM 1 & 1 & 26.0 & 15 \\
\hline D 1 & 101781 & $A M 1$ & 1 & 28.0 & 5 \\
\hline D 1 & 101781 & $A M 1$ & 4 & 4.5 & 25 \\
\hline D 1 & 101781 & AM 1 & 4 & 12.8 & 58 \\
\hline D1 & 101781 & $A M 1$ & 4 & 21.5 & 27 \\
\hline D 1 & 101781 & $A M 1$ & 4 & 32.0 & 72 \\
\hline D 1 & 101781 & AM 1 & 4 & 32.0 & 72 \\
\hline D 1 & 101781 & AM 1 & 4 & 75.0 & 74 \\
\hline D 1 & 101781 & AM 1 & 4 & 75.0 & 74 \\
\hline$D 1$ & 101781 & $A M 1$ & 4 & 75.0 & 74 \\
\hline D 1 & 101781 & $A M 1$ & 13 & 31.0 & 40 \\
\hline 01 & 101781 & AM 1 & 4 & 40.0 & 73 \\
\hline D 1 & 101781 & AM 1 & 4 & 55.0 & 90 \\
\hline D 1 & 101781 & AN11 & 4 & 23.0 & 36 \\
\hline D 1 & 101781 & AM1 & 1 & 37.0 & 60 \\
\hline D 1 & 101781 & AM 1 & 4 & 36.0 & 52 \\
\hline DI & 101781 & AM 1 & 4 & 27.0 & 75 \\
\hline D 1 & 101781 & AM1 & 1 & 20.0 & 50 \\
\hline D 1 & 101781 & AM1 & 17 & 32.0 & 50 \\
\hline D 1 & 101781 & AM 1 & 2 & 31.0 & 57 \\
\hline D1 & 101781 & AM1 & 1 & 55.0 & 11 \\
\hline D1 & 101781 & AM1 & 1 & 55.0 & 11 \\
\hline D 1 & 101781 & AM 1 & 1 & 55.0 & 11 \\
\hline D1 & 101781 & AM1 & 1 & 55.0 & 11 \\
\hline D1 & 101781 & AM1 1 & 1 & 25.0 & 20 \\
\hline D1 & 101781 & AM1 & 4 & 40.0 & 69 \\
\hline D1 & 101781 & AM1 & 4 & 40.0 & 69 \\
\hline D 1 & 101781 & AM1 & 4 & 40.0 & 69 \\
\hline D1 & 101781 & AM1 & 4 & 40.0 & 69 \\
\hline D1 & 101781 & AM1 1 & 4 & 40.0 & 69 \\
\hline
\end{tabular}

C. 3 


\begin{tabular}{|c|c|c|c|c|c|}
\hline Site & Date & Time & $\begin{array}{c}\text { Species } \\
\text { Code } \\
\end{array}$ & $\begin{array}{c}\text { Distance } \\
(\mathrm{m}) \\
\end{array}$ & $\begin{array}{c}\text { Angle } \\
\text { (Degrees) } \\
\end{array}$ \\
\hline D2 & 101781 & AM2 & 1 & 17.0 & 40 \\
\hline D 2 & 101781 & AM2 & 1 & 17.3 & 60 \\
\hline D2 & 101781 & AM2 & 2 & 9.0 & 60 \\
\hline $\mathrm{D} 2$ & 101781 & AM2 & 2 & 24.5 & 25 \\
\hline $\mathrm{D} 2$ & 101781 & AM2 & 2 & 34.0 & 30 \\
\hline $\mathrm{D} 2$ & 101781 & AM2 & 9 & 104.0 & 40 \\
\hline D 2 & 101781 & AM2 & 16 & 42.0 & 48 \\
\hline D2 & 101781 & AM2 & 16 & 42.0 & 48 \\
\hline D2 & 101781 & AM2 & 14 & 80.0 & 10 \\
\hline D 2 & 101781 & AM2 & 4 & 12.0 & 50 \\
\hline D2 & 101781 & AM2 & 4 & 12.0 & 50 \\
\hline D2 & 101781 & AM2 & 4 & 12.0 & 50 \\
\hline D 2 & 101781 & AM 2 & 4 & 12.0 & 50 \\
\hline D2 & 101781 & AM2 & 4 & 25.5 & 90 \\
\hline D 2 & 101781 & AM2 & 1 & 8.3 & 22 \\
\hline R1 & 101781 & PM1 & 4 & 36.0 & 85 \\
\hline R 1 & 101781 & PM1 & 4 & 36.0 & 85 \\
\hline R 1 & 101781 & PM1 & 18 & 102.0 & 20 \\
\hline R1 & 101781 & PM1 1 & 4 & 13.0 & 5 \\
\hline R1 & 101781 & PM1. & 6 & 101.0 & 28 \\
\hline R1 & 101781 & PM1 & 6 & 101.0 & 28 \\
\hline R1 & 101781 & PM1 1 & 6 & 101.0 & 28 \\
\hline R 1 & 101781 & PM1 & 6 & 101.0 & 28 \\
\hline R1 & 101781 & PM 1 & 6 & 101.0 & 28 \\
\hline R1 & 101781 & PM1 & 6 & 101.0 & 28 \\
\hline R1 & 101781 & PM1 & 4 & 25.2 & 90 \\
\hline R 1 & 101781 & PM1 & 4 & 28.5 & 90 \\
\hline R1 & 101781 & PM1 & 4 & 28.5 & 90 \\
\hline R1 & 101781 & PM1 & 4 & 14.5 & 50 \\
\hline R1 & 101781 & PM1 & 4 & 14.5 & 50 \\
\hline R1 & 101781 & PM1 & 4 & 14.5 & 50 \\
\hline R1 & 101781 & PM1 & 4 & 20.5 & 15 \\
\hline R1 & 101781 & PM 1 & 4 & 20.5 & 10 \\
\hline R 1 & 101781 & PM1 & 4 & 22.0 & 7 \\
\hline R1 & 101781 & PM1 & 4 & 28.5 & 40 \\
\hline R1 & 101781 & PM1 & 4 & 15.5 & 20 \\
\hline R1 & 101781 & PM1 & 4 & 6.8 & 60 \\
\hline
\end{tabular}

C. 4 


$\begin{array}{lcccccc}\text { Site } & \text { Date } & \text { Time } & \begin{array}{c}\text { Species } \\ \text { Code }\end{array} & \begin{array}{c}\text { Distance } \\ \text { (m) }\end{array} & \begin{array}{c}\text { Angle } \\ \text { (Degrees) }\end{array} \\ \text { R2 } & 101781 & \text { PM2 } & 4 & & 26.5 & 80 \\ \text { R2 } & 101781 & \text { PM2 } & 4 & & 26.5 & 80 \\ \text { R2 } & 101781 & \text { PM2 } & 4 & & 26.5 & 80 \\ \text { R2 } & 101781 & \text { PM2 } & 8 & & 17.8 & 20 \\ \text { R2 } & 101781 & \text { PM2 } & 4 & & 10.5 & 30 \\ \text { R2 } & 101781 & \text { PM2 } & 1 & & 29.0 & 60 \\ \text { R2 } & 101781 & \text { PM2 } & 1 & & 29.0 & 60 \\ \text { R2 } & 101781 & \text { PM2 } & 1 & & 29.0 & 60 \\ \text { R2 } & 101781 & \text { PM2 } & 1 & & 29.0 & 60 \\ \text { R2 } & 101781 & \text { PM2 } & 1 & & 29.0 & 60 \\ \text { R2 } & 101781 & \text { PM2 } & 1 & & 29.0 & 60 \\ \text { R2 } & 101781 & \text { PM2 } & 4 & 34.0 & 37 \\ \text { R2 } & 101781 & \text { PM2 } & 4 & 34.0 & 37 \\ \text { R2 } & 101781 & \text { PM2 } & 4 & 20.0 & 15\end{array}$




\begin{tabular}{|c|c|c|c|c|c|}
\hline site & Date & Time & $\begin{array}{c}\text { Species } \\
\text { Code } \\
\end{array}$ & $\begin{array}{c}\text { Distance } \\
(m) \\
\end{array}$ & $\begin{array}{c}\text { Angle } \\
\text { (Degrees) }\end{array}$ \\
\hline$R 2$ & 101881 & AM 1 & 4 & 4.5 & 5 \\
\hline R2 & 101881 & AM 1 & 5 & 35.0 & 26 \\
\hline R2 & 101881 & $A M 1$ & 1 & 19.0 & 60 \\
\hline R2 & 101881 & AM 1 & 1 & 85.0 & 45 \\
\hline R2 & 101881 & AM 1 & 1 & 60.0 & 40 \\
\hline R2 & 101881 & $A M 1$ & 1 & 60.0 & 40 \\
\hline R2 & 101881 & AM1 1 & 1 & 80.0 & 40 \\
\hline R2 & 101881 & AM 1 & 1 & 52.0 & 35 \\
\hline R2 & 101881 & AM 1 & 1 & 52.0 & 40 \\
\hline R 2 & 101881 & AM 1 & 1 & 42.5 & 5 \\
\hline D 1 & 101881 & AM2 & 4 & 18.2 & 90 \\
\hline D 1 & 101881 & AM2 & 4 & 21.5 & 83 \\
\hline D 1 & 101881 & AM2 & 4 & 21.5 & 83 \\
\hline D 1 & 101881 & AM2 & 8 & 20.5 & 66 \\
\hline D 1 & 101881 & AM2 & 4 & 4.5 & 90 \\
\hline D 1 & 101881 & AM2 & 1 & 7.5 & 55 \\
\hline D 2 & 101881 & PM1 & 4 & 31.0 & 12 \\
\hline D 2 & 101881 & PM1 & 18 & 18.5 & 75 \\
\hline D2 & 101881 & PM 1 & 11 & 24.5 & 52 \\
\hline D2 & 101881 & PM1 1 & 2 & 7.5 & 18 \\
\hline D 2 & 101881 & PM1 & 4 & 22.8 & 66 \\
\hline D2 & 101881 & $P M 1$ & 5 & 36.0 & 90 \\
\hline D2 & 101881 & $P M 1$ & 5 & 36.0 & 90 \\
\hline D 2 & 101881 & PM 1 & 5 & 36.0 & 90 \\
\hline D2 & 101881 & PM 1 & 5 & 92.0 & 88 \\
\hline R 1 & 101881 & FH2 & 4 & 44.0 & 80 \\
\hline R 1 & 101881 & PM2 & 4 & 80.0 & 2 \\
\hline R1 & 101881 & PM2 & 4 & 80.0 & 7 \\
\hline R1 & 101881 & PM2 & 4 & 39.0 & 22 \\
\hline R1 & 101881 & PM2 & 4 & 21.5 & 43 \\
\hline R1 & 101881 & PM2 & 14 & 22.0 & 38 \\
\hline
\end{tabular}




\begin{tabular}{|c|c|c|c|c|c|}
\hline site & Date & Time & $\begin{array}{c}\text { Species } \\
\text { Code } \\
\end{array}$ & $\begin{array}{c}\text { Distance } \\
\begin{array}{c}(\mathrm{m}) \\
\end{array}\end{array}$ & $\begin{array}{c}\text { Angle } \\
\text { (Degrees) }\end{array}$ \\
\hline $\begin{array}{l}\mathrm{D} 2 \\
\mathrm{D} 2 \\
\mathrm{D} 2 \\
\mathrm{D} 2 \\
\mathrm{D} 2 \\
\mathrm{D} 2 \\
\mathrm{D} 2 \\
\mathrm{D} 2 \\
\mathrm{D} 2 \\
\mathrm{D} 2\end{array}$ & $\begin{array}{l}102081 \\
102081 \\
102081 \\
102081 \\
102081 \\
102081 \\
102081 \\
102081 \\
102081 \\
102081\end{array}$ & $\begin{array}{l}A M 1 \\
A M 1 \\
A M 1 \\
A M 1 \\
A M 1 \\
A M 1 \\
A M 1 \\
A M 1 \\
A M 1 \\
A M 1\end{array}$ & $\begin{array}{l}7 \\
4 \\
4 \\
4 \\
1 \\
1 \\
1 \\
2 \\
1 \\
1\end{array}$ & $\begin{array}{r}16.0 \\
31.0 \\
31.0 \\
22.0 \\
34.0 \\
31.0 \\
42.0 \\
50.0 \\
.14 .0 \\
24.0\end{array}$ & $\begin{array}{l}72 \\
42 \\
42 \\
66 \\
40 \\
80 \\
60 \\
90 \\
10 \\
82\end{array}$ \\
\hline $\begin{array}{l}\text { R1 } \\
\text { R1 } \\
\text { R1 } \\
\text { R1 } \\
\text { R1 } \\
\text { R1 } \\
\text { R1 } \\
\text { R1 } \\
\text { R1 } \\
\text { R1 } \\
\text { R1 }\end{array}$ & $\begin{array}{l}102081 \\
102081 \\
102081 \\
102081 \\
102081 \\
102081 \\
102081 \\
102081 \\
102081 \\
102081 \\
102081\end{array}$ & $\begin{array}{l}\text { AM2 } \\
\text { AM2 } \\
\text { AM2 } \\
\text { AM2 } \\
\text { AM2 } \\
\text { AM2 } \\
\text { AM2 } \\
\text { AM2 } \\
\text { AM2 } \\
\text { AM2 } \\
\text { AM2 }\end{array}$ & $\begin{array}{l}4 \\
4 \\
4 \\
4 \\
4 \\
4 \\
4 \\
4 \\
4 \\
4 \\
4\end{array}$ & $\begin{array}{r}5.0 \\
12.0 \\
12.0 \\
7.0 \\
12.0 \\
18.0 \\
37.0 \\
6.0 \\
6.0 \\
14.0 \\
17.0\end{array}$ & $\begin{array}{r}20 \\
45 \\
45 \\
60 \\
30 \\
22 \\
18 \\
8 \\
8 \\
50 \\
65\end{array}$ \\
\hline $\begin{array}{l}\text { R2 } \\
\text { R2 } \\
\text { R2 } \\
\text { R2 } \\
\text { R2 } \\
\text { R2 }\end{array}$ & $\begin{array}{l}102081 \\
102081 \\
102081 \\
102081 \\
102081 \\
102081\end{array}$ & $\begin{array}{l}\text { PM1 } \\
\text { PM1 } \\
\text { PM1 } \\
\text { PM1 } \\
\text { PM1 } \\
\text { PM1 }\end{array}$ & $\begin{array}{r}17 \\
4 \\
5 \\
5 \\
5 \\
5\end{array}$ & $\begin{array}{l}68.0 \\
19.0 \\
60.0 \\
60.0 \\
22.0 \\
24.5\end{array}$ & $\begin{array}{l}76 \\
16 \\
90 \\
90 \\
80 \\
28\end{array}$ \\
\hline $\begin{array}{l}D 1 \\
D 1 \\
D 1 \\
D 1 \\
D 1 \\
D 1 \\
D 1 \\
D 1 \\
D 1 \\
D 1 \\
D 1 \\
D 1 \\
D 1 \\
D 1 \\
D 1 \\
D 1\end{array}$ & $\begin{array}{l}102081 \\
102081 \\
102081 \\
102081 \\
102081 \\
102081 \\
102081 \\
102081 \\
102081 \\
102081 \\
102081 \\
102081 \\
102081 \\
102081\end{array}$ & $\begin{array}{l}\text { PM2 } \\
\text { PM2 } \\
\text { PM2 } \\
\text { PM2 } \\
\text { PM2 } \\
\text { PM2 } \\
\text { PM2 } \\
\text { PM2 } \\
\text { PM2 } \\
\text { PM2 } \\
\text { PM2 } \\
\text { PM2 } \\
\text { PM2 } \\
\text { PM2 }\end{array}$ & $\begin{array}{l}2 \\
4 \\
4 \\
4 \\
4 \\
4 \\
4 \\
4 \\
4 \\
4 \\
4 \\
4 \\
4 \\
4\end{array}$ & $\begin{array}{r}51.5 \\
10.5 \\
9.8 \\
22.0 \\
20.8 \\
20.8 \\
20.8 \\
14.0 \\
14.0 \\
14.0 \\
10.5 \\
10.5 \\
21.5 \\
36.5\end{array}$ & $\begin{array}{l}15 \\
12 \\
14 \\
45 \\
55 \\
55 \\
55 \\
70 \\
70 \\
70 \\
70 \\
70 \\
54 \\
26\end{array}$ \\
\hline
\end{tabular}




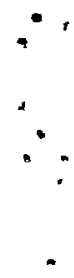

$+$ $\therefore$ 


\section{DISTRI BUTION}

No. of

Coples

OFFSITE

$$
\begin{aligned}
& \text { A. A. Churm } \\
& \text { DOE Patent DIvision } \\
& 9800 \text { S. Cass Avenue } \\
& \text { Argonne, IL } 60439
\end{aligned}
$$

27 DOE Technical Information Center

25 Dr. Donald Dletz

U. S. Mineral Management

Service

131 North Sixth Suite 300

Grand Junction, CO 81501

3 Dr. Ralph Franklin

U. S. Department of Energy

Ecological Research Division ER-75, GTN

Washington, DC 20555

Dr. D. Heyward Hamilton

U. S. Department of Energy

Ecological Research Division

EV-34, GTN

Washington, DC 20555

2 Dr. Douglas S. Robson

Biometrics Unit

337 Warren $\mathrm{Hall}$

Cornell University

Ithaca, NY 14853
No. of

Coples

ONSITE

DOE Richland Operations Office

H. E. Ransom

53 Pacific Northwest Laboratory

L. L. Eberhard $t$

R. E. Fitzner (4)

K. A. Gano (4)

D. H. McKenzie (5)

M. A. Simmons

J. R. Skalski (25)

J. M. Thomas

B. E. Vaughan (2)

M. L. Warner

R. E. Wildung (2)

Publishing Coordination (2)

Technical Information (5) 


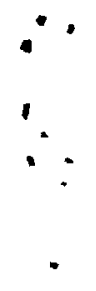

